Bouchard RA, ET AL. STRuCTURE-FunCtion ANALYSis of GLOBAL Pharmaceutical Linkage Regulations. MinNESOTA JOURNAL OF LAW, SCIENCE \& TECHNOLOGY. 2011;12(2):391-457.

\title{
Articles
}

\section{Structure-Function Analysis of Global Pharmaceutical Linkage Regulations}

\author{
Ron A. Bouchard, Dan Cahoy, Bengt Domeij, \\ Graham Dutfield, Tom Faunce, Aidan Hollis, Paul \\ Jones, Feroz Ali Khader, Joel Lexchin, Heesob \\ Nam, \& Juan Luis Serrano*
}

I. INTRODUCTION 392

II. EVOLUTION OF GLOBAL PHARMACEUTICAL LINKAGE ......................................................... 393

III. METHODOLOGY \& RESEARCH QUESTIONS ......... 401

IV. STRUCTURAL \& FUNCTIONAL ASPECTS OF PHARMACEUTICAL LINKAGE

A. Original Policy Intent ......................................... 406

B. Legal Checks and Balances ................................... 434

C. Convergence of Public Health and Economic Policy

D. Expansion of Linkage Beyond the Drug Approval-Drug Patenting Nexus....

E. Rights Layering v. Single Point Mechanism for Incenting Innovation

(C) 2011 Ron A. Bouchard, Dan Cahoy, Bengt Domeij, Graham Dutfield, Tom Faunce, Aidan Hollis, Paul Jones, Feroz Ali Khader, Joel Lexchin, Heesob Nam, \& Juan Luis Serrano.

* Ron A. Bouchard, Associate Professor, Faculties of Law and Medicine, University of Manitoba, Canada; Dan Cahoy, Smeal College of Business, Penn State University, United States; Bengt Domeij, Faculty of Law, Uppala Universitet, Sweden; Graham Dutfield, Faculty of Law, University of Leeds, U.K.; Tom Faunce, Faculty of Law, Australian National University, Australia; Aidan Hollis, Faculty of Social Sciences, University of Calgary, Canada, Paul Jones, Jones \& Co., Toronto, Beijing; Feroz Ali Khader, Ali Associates, Advocates, India; Joel Lexchin, Faculty of Health, York University, Canada; Heesob Nam, Centre for Health and Social Change, South Korea; Juan Luis Serrano, Olivares \& CIA, Mexico. The research was funded in part by a New Investigator Award from the Canadian Institutes for Health Research (RAB). 
F. Role of Empirical Studies for Public Health Systems 446

V. SUMMARY \& CONCLUSIONS 454

\section{INTRODUCTION}

Prompt and affordable access to essential medicines is a component of almost all domestic and global public health models. As is now well known, the availability and costs of both brand and generic drugs are a function of traditional patent law incentives. Less known, however, is that generic entry is controlled increasingly through an emerging form of global intellectual property law referred to as "linkage regulations." Linkage regulations tie generic drug approval and, thus, access to essential medications to existing drug patents through potentially long and costly litigation. The linkage regime is in the process of rapidly spreading worldwide through international free trade agreements. Even so, very little is known about how the regulations work in developed nations let alone how they impact public health systems across international borders. The authors constitute a network of eleven health policy experts and practicing lawyers in nine countries including those with mature linkage regulations, those with new regulations, those without regulations but with practices that parallel linkage, and those where regulations are currently subject to intense public debate and litigation.

The study of structure-function relationships in living systems, both at the micro and macro levels, has served science especially well over the last century. The term "structurefunction" refers to the relationship between the structural and functional elements of a system. As demonstrated by pioneering work in general systems theory and systems biology over the last half century, the interaction between structural and functional elements in a given system is bi-directional; not only does structure influence function, but function also influences structure. The structure-function paradigm applies fundamentally to law in two ways. First, governments have specific legal and policy goals and these goals are expressed in the form of statutes and regulations. Second, these policy goals are reviewed by courts in judicial and are often revisited by governments in the context of their law reform efforts. 
Here, we propose a novel structure-function framework to conduct a comparative legal analysis of global pharmaceutical linkage, with the aim of obtaining critical information about the costs and benefits of tying pharmaceutical innovation and generic drug availability to drug patenting. A major goal of the research is to investigate the structural and functional aspects of global linkage regulations as they relate to drug availability, costs, and expenditures on the one hand and incentives for innovation and protection of rights on the other. Nations and economic regions analyzed include the United States, Canada, Mexico, Australia, India, China, South Korea, and the European Union. The structural and functional aspects we discuss here include: assessment in each jurisdiction of the original policy intent underpinning linkage; the manner in which public health policy and economic policy are perceived by governments and the courts to converge or diverge through linkage; the specific legal checks and balances designed specifically to maintain balance between the interests of brand and generic firms; the growing expansion of linkage beyond the drug approval-drug patenting nexus to encompass drug pricing and reimbursement; and the role of empirical studies to establish the legal legitimacy of linkage regulations. A second goal of our work is to assist domestic and global governments and legal systems working with linkage regimes to balance the production of new and innovative drugs with timely generic entry and, thus, to lower public health costs and increase access to essential medicines.

\section{EVOLUTION OF GLOBAL PHARMACEUTICAL LINKAGE}

Access to essential medicines is a significant component of most models of domestic and global public health and is central to the goal of ensuring value for money regarding drug costs and expenditures. The availability and costs of new and generic drugs is a function of traditional patent law incentives and emerging linkage regulations. ${ }^{1}$ Patent law is a well described, ${ }^{2}$

1. See Ron A. Bouchard, Living Separate and Apart is Never Easy: Inventive Capacity of the PHOSITA as the Tie That Binds Obviousness and Inventiveness, 4 U. OTTAWA L. \& TECH. J. 1, 53-55 (2007).

2. See generally KENNETH ARROW, ECONOMIC WELFARE AND THE ALLOCATION OF RESOURCES FOR INNOVATION, reprinted in THE RATE AND DIRECTION OF INVENTIVE ACTIVITY: ECONOMIC AND SOCIAL FACTORS 609-24 (Richard Nelson ed., 1962) (explaining the economic roles of information and 
if controversial, ${ }^{3}$ policy lever for stimulating drug development. ${ }^{4}$ Linkage regulations tie generic drug availability to existing drug patents by connecting approval to the resolution of patent validity or infringement. 5 This can result in

innovation); DAVID VAVER, INTELleCtuAl PROPERTY RIGHTS: CRITICAL CONCEPTS IN LAW (2006) (providing an overview of all aspects of patent law); Dan L. Burk \& Mark A. Lemley, Policy Levers in Patent Law, 89 VA. L. ReV. $1575,1595-1629$ (2003) (outlining the ways in which patent law varies and its different theoretical approaches); Robert P. Merges \& Richard R. Nelson, On the Complex Economics of Patent Scope, 90 COLUM. L. REV. 839, 844-68 (1990) (explaining various patent law doctrines). For an account of the relationship between patents and drug discovery, development, and marketing from the earliest days of the industry to the present, see GRAHAM DUTFIELD, INTELLECTUAL PROPERTY Rights AND THE LifE SCIENCE INDUSTRIES: PAST, PRESENT AND FUTURE 157-82 (2d ed. 2009).

3. James Bessen \& Michael J. Meurer, Patent FAIlure: How JudGES, BuREAUCRATS, AND LAWYERS PUT INNOVATORS AT RISK 3, 11-28 (2008); Michele BOLDRIN \& DAVID K. LEVINE, AGAINST INTELlECTUAL MONOPOLY 68-91, 149-80 (2008) [hereinafter BOLDRIN \& LEVINE, InTEllectual Monopoly]; SHELdon KrIMSKY, ScIENCE IN THE PRIVATE INTEREST: HAS THE LURE OF PROFITS CORRUPTED BIOMEDICAL RESEARCH? 13 (2003); Michele Boldrin \& David K. Levine, The Economics of Ideas and Intellectual Property, 102 PNAS 1252, 1256 (2005); Adam Jaffe, The U.S. Patent System in Transition: Policy Innovation and the Innovation Process, 29 RES. POL'Y 531, 531-32 (2000); Roberto Mazzoleni \& Richard R. Nelson, The Benefits and Costs of Strong Patent Protection: A Contribution to the Current Debate, 27 RES. PoL'Y 273, 274-75 (1998); Keith Pavitt, National Policies for Technical Change: Where are the Increasing Returns to Economic Research?, 93 PNAS 12,693, 12,694-95 (1996).

4. Ron A. Bouchard, KSR v. Teleflex Part 1: Impact of U.S. Supreme Court Patent Law on Canadian Intellectual Property and Regulatory Rights Landscape, 15 HEALTH L.J. 221, 239-40 (2008) [hereinafter Bouchard, KSR v. Teleflex Part 1]; Bouchard, supra note 1, at 23; Ron A. Bouchard, Should Scientific Research in the Lead-Up to Invention Vitiate Obviousness Under the Patented Medicines (Notice Of Compliance) Regulations: To Test or Not to Test?, 6 CAN. J.L. \& TECH. 1, 11 (2007); Thomas A Faunce \& Joel Lexchin, 'Linkage' Pharmaceutical Evergreening in Canada and Australia, AUsTL. \& N.Z. HEALTH POL'Y, June 1, 2007, available at http://www.anzhealthpolicy.com/content/4/1/8; Paul Jones, KSR and the Supreme Court: The silence is deafening, 53 ANTITRUsT BULL. 849, 852 (2008).

5. Patented Medicines (Notice of Compliance) Regulations, SOR/1993133 (Can.). For a review of Canadian linkage regulations, see Ron A. Bouchard, I'm Still Your Baby: Canada's Continuing Support of U.S. Linkage Regulations for Pharmaceuticals, 15 MARQ. InTELL. PROP. L. REV. 71, 73 (2010) [hereinafter Bouchard, I'm Still Your Baby]; Edward Hore, A Comparison of United States and Canadian Laws as They Affect Generic Pharmaceutical Market Entry, 55 FOOD \& DRUG L.J. 373, 384-87 (2000); Joel Lexchin, After Compulsory Licensing: Coming Issues in Canadian Pharmaceutical Policy and Politics, 40 HeALTH PoL'y 69, 70-71 (1997). Linkage can be referred to as that between generic drug safety, quality, and efficacy approval to the assessment of potential patent infringement. See 
long and costly litigation, the costs of which are ultimately borne by consumers. ${ }^{6}$

The patent system has been in operation for over 500 years, with early patent laws in Italy and the United Kingdom. ${ }^{7}$ By contrast, the linkage regime has only been in existence for about twenty-five years following passage of the Drug Price Competition and Patent Term Restoration Act, (Hatch-Waxman Act) in the United States in $1984^{8}$ and the Canadian Patented Medicines (Notice of Compliance) Regulations (NOC Regulations). ${ }^{9}$ In both originating jurisdictions, the linkage regime was brought in explicitly to balance the competing policy goals of stimulating the

Thomas Faunce, Global Intellectual Property Protection for Innovative Pharmaceuticals: Challenges for Bioethics and Health Law, in GLOBALIZATION AND Health: Challenges For Health LaW AND Bioethics 87, 91 (Belinda Bennett \& George F. Tomossy eds., 2006), available at http://papers.ssrn.com/sol3/papers.cfm?abstract_id=1409211. For the sake of simplicity, the term "linkage" is used in this article to refer to the nexus between drug approval and drug patenting.

6. See BOLDRIN \& LEVINE, InTELLECTUAL MONOPOLY, supra note 3, at 73-82; Jean O. Lanjouw \& William Jack, Trading Up: How Much Should Poor Countries Pay to Support Pharmaceutical Innovation?, 4 CENTER FOR GLOBAL DEV. BRIEF 1, 1-2 (2004).

7. See BoldRIN \& LEVINe, InTELleCtuAl Monopoly, supra note 3, at 212-242; DUTFIELD, supra note 2.

8. Drug Price Competition and Patent Term Restoration (HatchWaxman), Pub. L. No. 98-417, 98 Stat. 1585 (codified as amended at 21 U.S.C. $\S 355$ (2000)). For a description of U.S. linkage laws, see Jeremy Bulow, The Gaming of Pharmaceutical Patents, in 4 INNOVATION POL'Y \& THE ECON. 145, 147-51 (2004), available at http://www.nber.org/chapters/c10802.pdf; Andrew A. Caffrey, III \& Jonathan M. Rotter, Consumer Protection, Patents and Procedure: Generic Drug Market Entry and the Need to Reform the HatchWaxman Act, 9 VA. J.L. \& TECH. 1, 4-7 (2004); Rebecca S. Eisenberg, Patents, Product Exclusivity, and Information Dissemination: How Law Directs Biopharmaceutical Research and Development, 72 FORDHAM L. REV. 477, 48286 (2003); Gerald J. Mossinghoff, Overview of the Hatch-Waxman Act and Its Impact on the Drug Development Process, 54 FoOD \& DRUG L.J. 187, 189-92 (1999); Matthew Avery, Note, Continuing Abuse of the Hatch-Waxman Act by Pharmaceutical Patent Holders and the Failure of the 2003 Amendments, 60 HASTINGS L.J. 171, 174-78 (2008); Richard A. Epstein \& Bruce N. Kuhlik, Navigating the Anticommons for Pharmaceutical Patents: Steady the Course on Hatch-Waxman 1-14 (Univ. of Chi. Law \& Econ., Working Paper No. 209, 2004).

9. See Christopher Scott Harrison, Protection of Pharmaceuticals as Foreign Policy: The Canada-U.S. Trade Agreement and Bill C-22 Versus the North American Free Trade Agreement and Bill C-91, 26 N.C. J. INT'L L. \& CoM. REG. 457, 521-25 (2001); Hore, supra note 5, at 381-87; Robert S. Tancer, Foreign Investment in North America and the Pharmaceutical Industry in Canada, 39 THE INT'L EXECUTIVE 283, 293 (1997) 
development of new and innovative drugs and facilitating the timely entry of generic drugs. ${ }^{10}$ Compared to the patent system, the linkage regime therefore represents a novel and emerging intellectual property paradigm for protecting pharmaceutical inventions. Given the comparative youth of the pharmaceutical linkage regime, it is not surprising that empirical data is only now beginning to be reported on the impact of linking drug approval to drug patenting on the twin policy goals of encouraging the development of new drugs and the timely entry of generic competitors. This includes earlier qualitative studies of gaming the automatic stay and other provisions in the originating American and Canadian linkage regimes, ${ }^{11}$ as well as newer quantitative empirical studies of the performance and outputs of both systems over time. ${ }^{12}$

Of growing interest from a global public health perspective, pharmaceutical linkage is no longer restricted to the North American context or solely to the drug approval-drug patenting nexus. Indeed, in 2011 we are witnessing the rapid spread of the linkage regime on a global level including to developing countries where access to generics is both of more significance and more problematic. ${ }^{13}$ This is due to a growing number of

10. Bouchard, I'm Still Your Baby, supra note 5, at 108; Avery, supra note 8 , at 175 .

11. See Fed. Trade Comm'n, Generic Drug Entry Prior to Patent EXPIRATION: AN FTC STUDY, at i-xi (July 2002), available at http://www.ftc.gov/os/2002/07/genericdrugstudy.pdf; see also Caffrey \& Rotter, supra note 8, at 35-37. See generally Bulow, supra note 8; Epstein and Kuhlik, supra note 8; Avery, supra note 8.

12. Ron A. Bouchard et al., Empirical Analysis of Drug Approval-Drug Patenting Linkage for High Value Pharmaceuticals, 8 NW. J. TECH. \& INTELL. PROP. 174, 174, 192-217 (2010) [hereinafter Bouchard et al., Drug ApprovalDrug Patenting]; Ron A. Bouchard et al., The Pas de Deux of Pharmaceutical Regulation and Innovation: Who's Leading Whom?, 24 BERKELEY TECH. L.J. 1461, 1486-1507 (2009) [hereinafter Bouchard et al., Who's Leading Whom?]; Monika Sawicka \& Ron A. Bouchard, Empirical Analysis of Drug Approval Data 2001-2008: Are Canadian Pharmaceutical Players "Doing More With Less"?, 3 MCGILL J.L. \& HEALTH 85, 88-104 (2009).

13. See Bouchard, I'm Still Your Baby, supra note 5, at 89 fig.5; C. Scott Hemphill \& Mark A. Lemley, Earning Exclusivity: Generic Drug Incentives and the Hatch-Waxman Act (Stanford Law and Economics Olin Working Paper No. 405, Columbia Law and Economics Working Paper No. 391, 2011), available at http://papers.ssrn.com/sol3/papers.cfm?abstract_id=1736822; C. Scott Hemphill \& Bhaven N. Sampat, When do Generics Challenge Drug Patents? 24-27 (The Ctr. for Law \& Econ. Studies at Columbia Univ. Sch. of Law, Working Paper No. 379, 2011), available at http://ssrn.com/abstract=1640512 (noting the impact of the Hatch-Waxman act 
multilateral and bilateral Free Trade Agreements (FTAs) involving the United States. ${ }^{14}$ Recent agreements include Trade Related Aspects of Intellectual Property Rights (TRIPS), 15 as well as narrower agreements between the United States, Canada and Mexico, ${ }^{16}$ Australia, ${ }^{17}$ and Korea, ${ }^{18}$ among others. ${ }^{19}$ The latter agreements require participating nations to incorporate linkage and other intellectual property provisions in their patent systems in exchange for preferential trade terms ${ }^{20}$ and are increasingly negotiated outside the purview of the World Trade Organization (WTO). As these provisions provide stronger intellectual property protection for drugs than provided for by TRIPS, they are referred to as "TRIPS-Plus." 21 The European Commission (E.C.) Pharmaceutical Inquiry recently reported several instances where member nations have attempted to institute pharmaceutical linkage regimes even though European Union law prohibits linkage. ${ }^{22}$

on drug patenting).

14. Carlos María Correa, Bilateral Free Trade Agreements and Access to Medicines, 84 BULL. OF THE WoRLD HEALTH ORG. 399, 399 (2006); Judit Rius Sanjuan, Patent-Registration Linkage, CONSUMER PROJECT ON TECHN. (Apr. 3, 2006), http://www.cptech.org/publications/CPTechDPNo2Linkage.pdf; Overview on Patent Linkage, Finston Consulting, 1-2 (Aug. 7, 2006), http://www.finstonconsulting.com/version03/files/Overview.pdf.

15. Agreement on Trade Related Aspects of Intellectual Property, Apr. 15, 1994, Marrakesh Agreement Establishing the World Trade Organization, Annex 1C, 186 U.N.T.S. 299, 33 I.L.M. 1197 (1994) (negotiated as part of the Uruguay Round (1986-1994) of the World Trade Organization's General Agreement on Tariffs and Trade (GATT)).

16. North American Free Trade Agreement, U.S.-Can.-Mex., Dec. 17, 1992, 32 I.L.M. 289, 605.

17. U.S.-Australia Free Trade Agreement, U.S.-Austl., May 18, 2004, 118 Stat. 919, available at http://www.ustr.gov/trade-agreements/free-tradeagreements/australian-fta/final-text.

18. Free Trade Agreement Between the United States of America and the Republic of Korea, U.S.-S. Kor., June 30, 2007 [hereinafter KorUS FTA], available at http://www.ustr.gov/trade-agreements/free-tradeagreements/korus-fta/final-text. The agreement between the United States and Korea is still pending ratification. See Prospects for Implementing the Korea-US Free Trade Agreement, PETERSON INST. FOR INT'L ECON., 1 (October 2010), http://www.iie.com/publications/pb/pb10-23.pdf.

19. Correa, supra note 14, at 401.

20. Faunce, supra note 5, at 93-101; Thomas Faunce \& Kathy Shats, Bilateral Trade Agreements as Drivers of National and Transnational Benefit from Health Technology Policy: Implications of Recent US Deals for Australian Negotiations with China and India, 62 AUsTL. J. INT'L AFF. 196, 202-07, 209 (2008).

21. Correa, supra note 14 , at 399 .

22. Dir. Gen. for Competition, Pharmaceutical Sector Inquiry Final 
The implications of pharmaceutical linkage to global public health are great. For example, recent work has shown that the linkage regime can extend cumulative patent terms for high value pharmaceuticals by as much as two-fold beyond that provided by the basic patent covering the compound. ${ }^{23}$ This is consistent with early predictions of the impact of linkage on market exclusivity by Schondelmeyer, ${ }^{24}$ based on experience with the U.S. linkage regime. ${ }^{25}$ An additional concern is that the extension of market exclusivity on brand drugs (and thus prolonged monopoly pricing) occurs even though fifty to seventy-five percent of patents challenged may be invalid or not infringed by the generic equivalent. ${ }^{26}$ Moreover, the scope of settlements between brand-name firms and generic firms under linkage not only renders consumers and other payers worse off than if generics were to win litigation on the merits, but it is possible that settlements of this nature may be

Report, at 23, SEC (2009) 952 final (July 7, 2009) [hereinafter Final Report], available

http://ec.europa.eu/competition/sectors/pharmaceuticals/inquiry/staff_working paper_part1.pdf. This theme is developed extensively in the Preliminary Report. Dir. Gen. for Competition, Pharmaceutical Sector Inquiry Preliminary Report, 15, 113, 261 (Nov. 8, 2008) [hereinafter Preliminary Report], available at

http://ec.europa.eu/competition/sectors/pharmaceuticals/inquiry/preliminary_r eport.pdf.

23. See Bouchard et al., Who's Leading Whom?, supra note 12 at 1498.

24. Dr. Stephen Schondelmeyer, a pharmacologist and health economist, gave evidence before the House of Commons to the effect that it is not the term of single patents that mattered most, but rather how patents add cumulatively to extend market exclusivity, a claim the government at the time vigorously denied. See Bouchard, I'm Still Your Baby, supra note 5, at 74 n.6.

25. Lara J. Glasgow, Stretching the Limits of Intellectual Property Rights: Has the Pharmaceutical Industry Gone Too Far? 41 IDEA 227, 233 n. 27 (2001) (citing The Gale Group, Intellectual Property Rules: A Delicate Balancing Act for Drug Development, 23 CHAIN DRUG REV. RX13 (2001), available

http://findarticles.com/p/articles/mi_hb3007/is_4_23/ai_n28824986/?tag=conten t;col1).

26. EdWARD Hore, PATENTLy ABsurd: Evergreening OF Pharmaceutical Patent PRotection Under the Patented Medicines (Notice of Compliance) Regulations of CANADA's Patent ACt 11 (2004) [hereinafter HORE, PATENTLY ABSURD], available at http://www.canadiangenerics.ca/en/news/docs/patently_absurd_04.pdf; FED. TRADE COMM'N, supra note 11, at vii-viii; Caffrey \& Rotter, supra note 8, at 40 n. 293. It should be noted, however, that this data is now somewhat old and requires updating for both the United States and Canada following amendments to the respective linkage regimes over the last half decade. 
necessary in the long run for 'generics to be adequately compensated for the risk of taking escalating litigation created by linkage laws. This creates a conflicting system in which governments with linkage regimes that limit the timely appearance of generics also depend on these firms to produce cost savings and limit the growth in pharmaceutical expenditures. A related issue is that costs of prolonged litigation are passed on to consumers, ${ }^{27}$ with differential costs to governments and the public in accordance with their system of drug reimbursement, ${ }^{28}$ public health, ${ }^{29}$ public-private discourse, ${ }^{30}$ and health equity. ${ }^{31}$

Considerations such as the forgoing must be balanced against the widely accepted need for innovative drugs in developed and developing nations; the presumption of patent validity in nations with established patent legislation; and the

27. See Boldrin \& LeVine, Intellectual Monopoly, supra note 3, at 73-77; Bulow, supra note 8, at 162-63.

28. Exploring Social Insurance: CAN a Dose of Europe Cure CANADiAn HEALth CARE FINANCE? 2-3 (Colleen M. Flood et al. eds., 2008).

29. See generally MARCIA ANGell, The Truth ABOUt the Drug Companies: How They DeceIve Us AND What to Do ABouT IT xiii-xv (2004) (describing drug development preferences for follow-on drugs, drug evergreening practices and the high costs of prescription drugs in America); Jerry Avorn, Powerful Medicines: The Benefits, Risks, AND Costs OF PRESCRIPTION DRUGS 183, 196-97 (2004) (detailing the impacts health care systems have on its patients and the role of follow-on drugs in dominating drug development); JAY S. CoHen, Overdose: The CASE AGAInst THE DRUG COMPANIES 176-94 (2001) (summarizing problems associated with the FDA, how this relates to drug development preferences and how these problems affect the public); PHILIP J. Hilts, ProteCting AMERICA's HEALTH: THE FDA, Business, AND ONE HundRED YeARS OF REgulation xii-xvi (2003) (describing the history of the Food and Drug Administration and associated shifts in drug development preferences); RAY MOYNIHAN \& ALAN CASSELS, SELLING SICKNESS: HOW THE WORLD'S BIGGEST PHARMACEUTICAL COMPANIES ARE TURNING Us ALL INTO PATIENTS xviii (2005) (noting that there is much debate surrounding the ways in which drug companies have become profitable and the relation of profit to follow-on drugs).

30. See Mary E. Wiktorowicz, Emergent Patterns in the Regulation of Pharmaceuticals: Institutions and Interests in the United States, Canada, Britain, and France, 28 J. HEALTH POL. POL'Y \& L. 615, 616, 620-21 (2003).

31. See Trudo Lemmens, Leopards in the Temple: Restoring Scientific Integrity to the Commercialized Research Scene, 32 J.L. MED. \& ETHICS 641, 647-52 (2004); Trudo Lemmens, Piercing the Veil of Corporate Secrecy about Clinical Trials, 34 Hastings CENTER ReP. 14, 15-16 (2004); Kevin Outterson, Pharmaceutical Arbitrage: Balancing Access and Innovation in International Prescription Drug Markets, 5 YAle J. HeAlth PoL'Y L. \& ETHICs 193, 193-96 (2005); Kevin Outterson, Should Access to Medicines and TRIPS Flexibilities Be Limited to Specific Diseases, 34 AM. J.L. \& MED. 279, 279-80 (2008). 
[Vol. 12:2

idea in law that if the state grants a party an exclusive legal right, it cannot turn around and grant another party permission to encroach upon that right without just cause. ${ }^{32}$

A related observation is that while the concept of pharmaceutical linkage is new compared to the patent system, there is already significant pressure to broaden it beyond drug approval to include linkage between patent rights and other regulatory aspects of drug approval and marketing. ${ }^{33}$ An expansive concept of linkage would differ significantly from the relatively discrete legal nexus between drug patents and marketed products envisioned by the architects of linkage in the United States and Canada. ${ }^{34}$ For example, the E.C. Pharmaceutical Sector Inquiry ${ }^{35}$ recently articulated a broad definition of pharmaceutical linkage, including linkage of patent status to formal legal proceedings between parties; patent settlements; as well as a wide range of interventions before national drug regulators, including those relating to

32. Doug Lichtman \& Mark A. Lemley, Rethinking Patent Law's Presumption of Validity, 60 STAN. L. REV. 45, 57-58 (2008).

33. See e.g., Final Report, supra note 22, at 130; Preliminary Report, supra note 22 , at 15 .

34. See HoRe, PATENTly ABSURD, supra note 26, at 5; Bouchard, I'm Still Your Baby, supra note 5, at 138-39; Caffrey \& Rotter, supra note 8, at 4-7. For elaboration, see also discussion infra Part IV.A.

35. Final Report, supra note 22, at 480 ("The Commission will continue to strictly enforce the applicable Community law and, for instance, act against patent linkage, as according to Community legislation, marketing authorisation bodies cannot take the patent status of the originator medicine into account when deciding on marketing authorisations of generic medicines."). In the Preliminary Report, the E.C. stated more specifically that patent-linkage is considered unlawful under Regulation (EC) No. 726/2004 and Directive (EC) No. 2001/83. Preliminary Report, supra note 22, at 14. Further elaboration is provided to the effect that

Patent linkage refers to the practice of linking the granting of MA, the pricing and reimbursement status or any regulatory approval for a generic medicinal product, to the status of a patent (application) for the originator reference product. Under EU law, it is not allowed to link marketing authorisation to the patent status of the originator reference product. Article 81 of the Regulation and Article 126 of the Directive provide that authorisation to market a medicinal product shall not be refused, suspended or revoked except on the grounds set out in the Regulation and the Directive. Since the status of a patent (application) is not included in the grounds set out in the Regulation and in the Directive, it cannot be used as an argument for refusing, suspending or revoking MA.

Final Report, supra note 22, at 130 (citations omitted). 
market approval, drug pricing, and reimbursement. 36 Moreover, a growing number of legal disputes have been reported whereby countries without linkage have attempted to import or export drugs. In some instances, the drug shipments are seized by other nations who allege that the shipments are in violation of domestic patent laws linked to international trade instruments such as TRIPS or other FTAs. ${ }^{37}$

An evolving landscape such as that reviewed thus far raises the question of whether the pharmaceutical industry is using linkage as an emerging stepping-stone in its efforts to reach across global borders to establish a uniform intellectual property regime in a distinctly non-uniform world. In this way, linkage regulations in respect of therapeutic products, have quietly emerged as a powerful driver of drug regulation, access to essential medication, and public health costs on the global stage.

\section{METHODOLOGY \& RESEARCH QUESTIONS}

When the group began its work, the obvious question to ask was, what should the focus be of future research on pharmaceutical linkage as it evolves over time from its North American roots? We noted with interest that the study of structure-function relationships in living systems, both at the micro and macro levels, has served the life sciences especially well over the last century. Structure-function analyses in the life sciences have led to numerous key insights into molecular, cellular, tissue, organ, and whole body functioning over the last half-century. For example, structure-function studies have

36. In the Preliminary Report, the E.C. noted that

Interventions before regulatory bodies (marketing authorisation authorities and pricing and reimbursement bodies) appear to be a standard tool in originator companies' toolbox. Although contacting the health authorities may address legitimate concerns, it can also be used to delay or block the marketing authorisation or the pricing or reimbursement status of the generic product. In particular, by suggesting that the generic product is less efficient or safe or is not equivalent, raising patent infringement issues concerning the generic product in question and alleging that any decision favourable to the generic company would make the authorities liable to patent infringement damages (patent linkage), originator companies gain time and can create delays in granting marketing approval for the generic product and its entry into the market.

Preliminary Report, supra note 22, at 314.

37. See, e.g., WTO Dispute over Seized Drug Shipment, PHARMALETTER (Feb. 18, 2009), http://www.thepharmaletter.com/file/91762/wto-dispute-overseized-drug-shipment.html. 
yielded detailed descriptions of drug, chemical and hormonal receptors, cell membrane and intracellular constituents, second messenger systems, chemical and hormonal mediation of intraorgan and inter-organ function. More recently, functional imaging techniques have revealed a remarkable degree of brain plasticity in the context of congenital and acquired disease states, including under circumstances where dysfunction was previously thought to be permanent.

As demonstrated by pioneering work in general systems theory and systems biology over the last half century, the interaction between structural and functional elements in a system is bi-directional; that is, not only does structure influence function, but function also influences structure. As discussed further below, this occurs through various feedback mechanisms. The structure-function paradigm applies fundamentally to law in two ways. First, because governments have specific legal and policy goals in mind when drafting law and regulations, and these goals are expressed in the form of discrete legal and regulatory language. Second because policy goals and statutory language employed by governments and administrative bodies are reviewable by the courts in judicial review and other proceedings and are often revisited by governments in the context of their law reform efforts.

The rapid spread of pharmaceutical linkage worldwide offers a unique and time sensitive opportunity to carry out empirical work on the system as it evolves globally, from its original locus in North America. A major goal of our work on global pharmaceutical linkage is to investigate the structural and functional aspects of different systems of linkage regulations and their relationship to drug availability costs and expenditures, balanced with incentives for innovation and protection of intellectual property rights.

As in other complex political, legal and economic systems, ${ }^{38}$ the pharmaceutical linkage network is assumed to have

38. Robert Jervis, System EFFects: Complexity IN POLITICAL AND SocIAL Life 260 (1997); Ravi Bhavnani, Agent Based Models in the Study of Ethnic Norms and Violence, in COMPLEXITY IN WORLD POLITICS: CONCEPTS AND Methods of A NeW Paradigm 121, 127 (Neil E. Harrison ed., 2006); Barry Bozeman, Public-Value Failure: When Efficient Markets May Not Do, 63 Pub. Admin. REv. 145, 154 (2002); Barry Bozeman \& Daniel Sarewitz, Public Values and Public Failure in US Science Policy, 32 SCI. \& PUB. POL'Y 119, 127 (2005); John D. Sterman, All Models Are Wrong: Reflections on Becoming a Systems Scientist, 18 SYS. DYNAMICS REV. 501, 524-26 (2002). 
structural and functional characteristics that can be identified and measured. These quantified characteristics, can then, in turn, serve as appropriate benchmarks to assess the performance of the system relative to its goals and objectives. Key decision makers, including brand and generic pharmaceutical firms, the courts, patent counsel, consumers, payers, and other actors, are assumed to interact in domestic and global networks through reasonably well-defined channels of communication. ${ }^{39}$ Complex systems are characterized by broad rules that have increasing applicability and universality as the symmetry and elegance of the rules increase. ${ }^{40}$ Indeed, previous work has demonstrated that this principle applies to innovation ecologies regulated by law, ${ }^{41}$ particularly those where large-scale public and private rights revolving around technology must be balanced. ${ }^{42}$

We use the term "structural" in this Article to refer to the broad administrative, legal, and policy attributes of the linkage regime in differing jurisdictions. Together, these attributes form the initial starting conditions for operation of linkage regimes. The initial starting conditions, as in dynamical physical systems, represent the sum of the political, economic, and public policy conditions that together form the "take-off" point for a new law and the conditions in which this law begins to operate. ${ }^{43}$ The structural aspect also encompasses the

39. See generally Peter Drahos, Intellectual Property and Pharmaceutical Markets: A Nodal Governance Approach, 77 TEMP. L. REV. 401, 423-24 (2004) (describing the concept of "nodal governance" and its relation to general systems theories).

40. See generally MurRay Gell-MANn, The QUARK AND THE JAGUAR: ADVENTURES IN THE SIMPLE AND THE COMPLEX 370-71 (1994). The practical implications of elegance and symmetry in physics and mathematics are explored elegantly by Gell-Mann in a videocast on the subject. See Murray Gell-Mann, Beauty and Truth in Physics: Murray Gell-Mann on TED.com, TED BLOG (Dec. 6, 2007), http://blog.ted.com/2007/12/murray_gellmann.php.

41. See Fred Gault \& Sasanne Huttner, Commentary, A Cat's Cradle for Policy, 455 NATURE 462 (2008); David H. Guston, Commentary, Innovation Policy: Not Just Jumbo Shrimp, 454 NATURE 940, (2008); William Wulf, Editorial, Changes in Innovation Ecology, 316 SCI. 1253 (2007).

42. Bouchard et al., Who's Leading Whom?, supra note 12, at 1513-15; Drahos, supra note 39; J.B. Ruhl, Regulation by Adaptive Management-Is It possible?, (2005) 7 MINN. J.L. SCI. \& TECH. 21, 25-27 (2005) [hereinafter Ruhl 2005].

43. ALBERT-LÁSZLÓ BARABÁSI, LINKED: HOW EVERYTHING IS CONNECTED TO Everything Else AND What It MeANs For Business, SCIENCE, AND EVERYDAY LIFE 93-107 (2003); JAMES GLEICK, CHAOS: MAKING A NEW SCIENCE 241-73 (1988); JOHN H. HOLLAND, ADAPTATION IN NATURAL AND 
specific legal mechanisms that drive operation of linkage regimes in various jurisdictions. Identifying the structural attributes and mechanisms of individual linkage systems is important; as combined they provide the benchmark from which to assess the successes and failures of local systems in operation and their potential to combine to form a global and integrated regulatory regime.

Our research thus far has identified a number of important structural aspects of pharmaceutical linkage, including: assessment in each jurisdiction of the original policy intent underpinning the linkage regime; the manner in which public health policy and economic policy is perceived by governments and the courts to converge or diverge through the linkage vector; the legal checks and balances found within the linkage regime designed specifically to maintain balance between the interests of brand and generic firms; the provisions in addition to linkage that were included in enabling legislation; the growing expansion of the linkage concept beyond the drug approval-drug patenting nexus to encompass that between patenting and international trade mechanisms; and how pharmaceutical linkage is in the process of informing the construction of new laws pertaining to follow-on biologics.

We use the term "functional" to refer to the outputs of the regulations in each jurisdiction, as well as how these outputs functionally interact across borders to operate as a coherent global regulatory regime. The functional aspects reflect the behavior of the system as it evolves with time away from the initial starting conditions, ${ }^{44}$ in this case the U.S. HatchWaxman regime. The functional aspects we have identified to

ARTificial Systems 6-9 (1992); John H. Holland, Hidden ORDER: How ADAPTATION BUILDS COMPLEXITY 60 (1992); $c$. STEVEN JOHNSON, EMERGEnce: The ConneCted Lives of Ants, BRAins, Cities, AND Software 104-10 (2001); STUART KAUfFMAN, AT HOME IN THE UnIVERSE: THE SEARCH FOR THE LAWS OF SELF-ORGANIZATION AND COMPLEXITY 75-82 (1995); see also GrEgoIRE NiCOLIS \& ILYA PRIGOGINE, EXPLORING COMPLEXITY: AN INTRODUCTION (1989); M. Mitchell WALDROP, COMPLEXITY: THE EMERGING SCIENCE AT THE EDGE OF ORDER AND CHAOs (1992); W. Brian Arthur, Positive Feedbacks in the Economy, 262 SCI. AM. 92 (1990).

44. Harrison, supra note 9, at 491-95 (2001); see also LES JOHNSTON \& ClifFord SHEARING, GOVERNING SECURITY: EXPLORATIONS IN POLICING AND JUSTICE 138-61 (2003); Scott Burris, Governance, Microgovernance, and Health, 77 TEMP. L. REV. 335, 357 (2004); Clifford Shearing \& Jennifer Wood, Nodal Governance, Democracy, and the New 'Denizens', 30 J.L. \& SoC'Y 400, 401-06. 
study include: the impact of linkage regulations on the development of new and innovative drugs; the manner in which this is balanced by the timely entry of generic drugs; the degree to which market exclusivity is or can be extended solely by operation of the linkage regime; how brand firms use the linkage system in order to extend market exclusivity on high value drugs; the costs to consumers or other payers of extended exclusivity; the costs of extended exclusivity based on patents that are ultimately found to be invalid or not infringed; the impact of differing mechanisms of regulatory oversight on drug pricing and reimbursement; and the role of empirical studies for the legitimacy of linkage regulations.

Complex legal, scientific, medical, and economic issues such as those encompassed by the linkage regime lend themselves well to study by a network, or consortium of scholars and practicing lawyers. ${ }^{45}$ A unique advantage of a network-based approach is that studying linkage in different jurisdictions allows for both: (1) an investigation of the structural and functional characteristics of local linkage regimes with different initial starting conditions and different legal mechanisms of operation; and (2) the identification of general rules of linkage as the different national forms of linkage interact and influence global pharmaceutical regulation. The former provides a descriptive mechanism for assessing the successes and failures of different regimes while the latter provides a prescriptive approach for key decision makers to revise, institute or abolish linkage regulations according to the goals and objectives of differing nations.

The objective of our research is to produce and utilize empirical knowledge relating to different linkage regimes as a knowledge translation tool for assessing the strengths, weaknesses, successes, and failures of pharmaceutical linkage in individual nations and how they combine to form a global

45. The authors represent nations with mature linkage regulations (United States, Canada), nascent regulations (Australia, China), those without regulations but with certain practices that operate to parallel linkage (E.U.), and those where both the existence and scope of linkage regulations are the subject of intense public scrutiny (India, Mexico, South Korea). The analytical framework presented in this Article was originally conceived as an application for funding to the primary Canadian medical research funding agency, which was not successful. However, the authors hope the work produced by the consortium is of assistance to the global intellectual property bar and national governments in their respective deliberations regarding pharmaceutical linkage. 
system of pharmaceutical linkage. Different economic, public health, and political systems present a different set of initial starting conditions not only for the de novo operation of linkage regulations in each jurisdiction as they come into force, but also for how these systems evolve, grow, and adapt to changing conditions over time. Indeed, our early data suggests substantial differences between jurisdictions in this regard. These differences may be fundamentally responsible for the opposition of certain nations and economic regions to pharmaceutical linkage, and the varying degrees of success of those employing them with the twin policy goals of encouraging the development of new and innovative drugs, while also facilitating the timely entry of generic drugs and access to essential medications.

\section{STRUCTURAL \& FUNCTIONAL ASPECTS OF PHARMACEUTICAL LINKAGE}

\section{A. ORIGINAL Policy INTENT}

An excellent starting point for a global analysis of pharmaceutical linkage is the "original policy intent" underpinning linkage in differing jurisdictions. Original policy intent presents a critical issue for determination of whether or not legislation is intra vires or ultra vires, as governments have specific legal and policy goals in mind when drafting laws and regulations that are reviewable by the courts. ${ }^{46}$

A number of questions arise as relevant to original policy intent as it pertains to different forms of linkage. In practice these can, and typically do, vary substantially from one nation to the next. This is not surprising given the differing political, economic, and technological landscapes involved. A related issue is when the policy grounds put forward are similar in varying jurisdictions, but the legal mechanisms underpinning operation of the linkage regime differ, with potentially varying outputs. How do the grounds offered in support of linkage relate to other mechanisms for intellectual property protection for pharmaceuticals, such as data protection, patent term extension, etc.? Have the mechanisms favoring legal protection

46. Cameron Hutchinson, Which Kraft of Statutory Interpretation? A Supreme Court of Canada Trilogy on Intellectual Property Law, 46 ALTA. L. REV. 1, 7, 20 (2008). 
of pharmaceutical products been balanced by other mechanisms in favor of price control? Our preliminary analysis indicates significant differences among jurisdictions. Some jurisdictions favor strong intellectual property protection and linkage regulations without price controls, some are considering price controls, and some express forms of antievergreening provisions ${ }^{47}$ balanced with regulation of generic drug prices.

For example, in the United States where the linkage regime first came into force, the purpose of the Hatch-Waxman Act was explicitly to balance two competing policy objectives: inducing brand pharmaceutical firms to make the investments necessary to research and develop new drug products, while enabling competitors to bring cheaper, generic copies of those drugs to market as soon as possible. ${ }^{48}$ Indeed, during free trade negotiations leading up to linkage in the United States, Canada, and Australia,49 claims were made that linkage regulations were necessary to provide incentives to firms to engage in high risk research and development. In each instance, universities were particularly keen to hitch their wagon to the regulations. ${ }^{50}$ Senator Hatch, at the time the American legislation came into force said "[t]he public receives the best of both worlds - cheaper drugs today and better drugs

47. Evergreening "is a potentially perjorative term that generally refers to the strategy of obtaining multiple patents that cover different aspects of the same product, typically by obtaining patents on improved versions of existing products." John R. Thomas, Cong. Research Serv., R40917, Patent "Evergreening": Issues in Innovation and Competition 1 (2009).

48. H.R. REP. No. 98-857, pt. 1, at 28 (1984); Mylan Pharm. v. Thompson, 268 F.3d 1323, 1326 (Fed. Cir. 2001) (quoting Abbott Lab. v. Young, 920 F.2d 984, 991 (D.C. Cir. 1990)) ("These provisions of the Hatch-Waxman Amendments 'emerged from Congress' efforts to balance two conflicting policy objectives: to induce name brand pharmaceutical firms to make the investments necessary to research and develop new drug products, while simultaneously enabling competitors to bring cheaper, generic copies of those drugs to market."').

49. See Bouchard, I'm Still Your Baby, supra note 5, at 75-76 (documenting an empirical study with a specific emphasis on Canada's pharmaceutical linkage regulatory regime and its operation within the Canadian legal system); Faunce \& Lexchin, supra note 5, at 4-8 (outlining the development of pharmaceutical linkage in Australia); Harrison, supra note 9, at 473-77 (detailing negotiations between the United States and Canada that involved changes to Canadian patent law in service of NAFTA and TRIPS); Tancer, supra note 9, at 285-87 (describing historical factors leading to pharmaceutical linkage in Canada).

50. See, e.g., Bouchard, I'm Still Your Baby, supra note 5, at 100 (speaking directly to Canadian Universities); Tancer, supra note 9, at 290. 
tomorrow." 51 The same is true in Canada, as outlined clearly in the government's Regulatory Impact Analysis Statements on the topic. ${ }^{52}$ Therefore, in addition to stimulating pioneering drug development, a second major policy goal of linkage was to facilitate timely generic entry. ${ }^{53}$

However, while the policy goals may be similar, the factual baseline for legislation may differ significantly in different nations, with the result that outcomes may change accordingly. The United States and Canada present an excellent case study in this regard. Prior to linkage in the Unites States, a large number of drugs were off patent yet not marketed by generics due in large part to regulatory costs resulting from the inability to rely on the data in the original approval. ${ }^{54}$ This mechanism was eventually provided by the Hatch-Waxman Amendments, which resulted in, notwithstanding a certain level of gaming of

51. Epstein \& Kuhlik, supra note 8, at 11 (quoting 130 ConG. REC. S23,764 (daily ed. Aug. 10, 1984) (statement of Sen. Orrin Hatch)).

52. Evidence of legislative intent regarding the "original policy intent" of encouraging development of new and innovative drugs can be found in both Regulatory Impact Analysis Statement (RIAS) and related Guidance Documents. See Regulations Amending the Patented Medicines (Notice of Compliance) Regulations, 138 CAN. GAZE. PART I 3718, 3723, available at http://www.gazette.gc.ca/archives/p1/2004/2004-12-11/pdf/g1-13850.pdf; Minister of Health, Guidance Document, Patented Medicines (Notice of COMPLIANCE) REGULATIONs [hereinafter GUIDANCE DOCUMENT], available at http://www.hc-sc.gc.ca/dhp-mps/alt_formats/pdf/prodpharma/applicdemande/guide-ld/patmedbrev/pmreg3_mbreg3-eng.pdf. An articulation of the government's pharmaceutical policy as it relates to the Notice of Compliance (NOC) Regulations can be found in the 2006 RIAS, which states:

The Government's pharmaceutical patent policy seeks to balance effective patent enforcement over new and innovative drugs with the timely market entry of their lower priced generic competitors. The current manner in which that balance is realized was established in 1993, with the enactment of Bill C-91, the Patent Act Amendment Act, 1992, S.C. 1993 , c. 2.

Bouchard et al., Drug Approval-Drug Patenting, supra note 12, at 181 n.44.

53. Daniel R. Cahoy, Patent Fences and Constitutional Fence Posts: Property Barriers to Pharmaceutical Importation, 15 FORDHAM INTELL. PROP. MEDIA \& ENT. L.J. 623, 633-34 (2005).

54. For example, in the United States generics could not use NDA holder's data to demonstrate safety and efficacy and were forced to conduct clinical trials to support market authorization. Avery, supra note 8, at 174-75. Before Hatch-Waxman, the U.S. Food and Drug Administration demonstrated that approximately 150 brand drugs were on the market with expired patents, but with no generic equivalents. This resulted in hundreds of million dollars in out of pocket consumer expenditures. H.R. REP. No. 98-857, pt. 2, at 27-33 (1984). 
the system, 55 the United States developing a strong generic industry that is paralleled by a strong brand pharmaceutical industry. In contrast, Canada had a substantial domestic generic industry prior to linkage predicated, in part, by provisions allowing for compulsory licensing of pharmaceuticals. ${ }^{56}$ The result of linkage in Canada, as some have claimed, is a diminished generic industry. 57 However, since many of the companies are privately held and do not disclose detailed financial data, this claim cannot be verified. Linkage, however, has not led to any change in the level of global competitiveness for national life science firms as originally anticipated, 58 and in fact Merck has recently closed its main Canadian research laboratory. 59

Given that the second and third entrant linkage regimes, Canada and Australia respectively, are separated by a decade, it is reasonable to conclude the Canadian linkage regime was viewed as a kind of "test case" for American trade negotiators. Further, it is reasonable to say, given the available evidence, that this discrete and time-gated yet natural experiment has been a success. Of interest, 25 years after Hatch-Waxman, a similar situation is currently developing in India and, perhaps, Italy. The former nation, which like Canada prior to linkage is home to a well-developed generic drug industry, is in the midst of an intense legal battle over whether or not to institute some form of pharmaceutical linkage. ${ }^{60}$ In contrast to the debates

55. Bulow, supra note 8, at 159-73; Caffrey \& Rotter, supra note 8, at 14; Aidan Hollis, Closing the FDA's Orange Book, REG., Winter 2007, at 14-17, available at http://www.cato.org/pubs/regulation/regv24n4/v24n4-2.pdf; Avery, supra note 8 , at 172 .

56. Harrison, supra note 9, at 487-60; Tancer supra note 9, at 283-84.

57. See HORE, PATENTLY ABSURD, supra note 26, at 3; Lexchin, supra note 5, at 72-73; Joel Lexchin, Intellectual Property Rights and the Canadian Pharmaceutical Marketplace: Where Do We Go from Here?, 35 InT'L. J. HEALTH SERV. 237, 243 (2005).

58. Cf. EXPeRT PANEL on COMmercialization, PeOPle \& EXCEllence: THE HEART OF SucCESsful COMMERCIALIZATION 6, 17 (2006) [hereinafter EXPERT PANEL], available at http://dsp-psd.pwgsc.gc.ca/Collection/Iu4-782006E-I.pdf (documenting Canada's struggle to improve their productivity growth).

59. Quebec Merck closure could mean 'brain drain': Pharmaceutical giant shuts 16 facilities, including Montreal-area research facility, CBCNEWS (July 8, 2010, 9:07 PM), http://www.cbc.ca/canada/montreal/story/2010/07/08/merckclosures.html.

60. In 2008, Bayer moved the Delhi High Court to seek a declaration against the drug regulatory authority, Drug Controller General of India (DCGI). See Bayer Corp. v. Union of India, LPA 443/2009 (Delhi H.C.) (India). 
over the reach of linkage in Canada, Australia and India, the law relating to linkage in Mexico has been interpreted explicitly to encompass the link between market authorization and patents. ${ }^{61}$ Linkage has recently been interpreted by the Mexican Supreme Court to include not only active ingredient patents, but also patents covering pharmaceutical formulations. ${ }^{62}$ Processes are still expressly excluded in Mexico; the inclusion of patents covering uses remains hotly contested. In this particular case, the policy intent does not seem to be derived from compliance with international treaties but instead for coherence within the system, where exclusive rights granted by government through a patent are not invaded through a marketing authorization granted by a separate branch of the same government.

In addition to jurisdictional variability in the establishment of the generic drug industry prior to linkage, another major comparative issue that we have identified is the use of the Bolar, or "safe harbor," provision as a policy lever in pharmaceutical linkage regimes. ${ }^{63}$ The impetus for a focus on the Bolar provision is that the legal nexus between drug approval and drug patenting under linkage can trace its history

The Court directed the DCGI to refrain from passing an order of market approval for an Indian generic company, Cipla for its generic version of the drug 'Soranib.' Id. para. 7. Bayer based its arguments on the assertion that Section two of the Drugs and Cosmetics Act read with section forty-eight of the Patents Act provided for the concept of patent linkage. Id. para. 8. Justice Ravindra Bhatt dismissed Bayer's arguments for creating linkage between patent grants and marketing approvals. Id. para. 7. Bayer appealed the decision of the Single Judge before a Division Bench of the Delhi High Court. Id. para. 1. The Division Bench dismissed the appeal. Id. para. 37. Bayer filed an appeal from decision of the Division Bench of the Delhi High Court to the Supreme Court of India; the Supreme Court dismissed Bayer's appeal refusing to interfere with the finding of the High Court of Delhi. India: Supreme Court Dismisses Bayer' Petition in Patent Linkage Matter, GENERIC PHARM. \& IP (Dec. 2, 2010), http://genericpharmaceuticals.blogspot.com/2010/12/indiasupreme-court-dismisses-bayer.html.

61. See Luis C. Schmidt, Mexico moves to improve Pharmaceutical Product Registration Process, OLIVARES \& CIA, http://www.olivares.com.mx/Knowledge/Articles/CopyrightArticles/Mexicomov estoimprovePharmaceuticalProductRegistrationProcess (last visited June 13, 2011).

62. Juan Serrano, Mexican Supreme Court Decides on Broad Interpretation of Linkage Regulations, PATENT Docs (Mar. 9, 2010, 11:43 PM), http://www.patentdocs.org/2010/03/mexican-supreme-court-decides-on-broadinterpretation-of-linkage-regulations.html.

63. See infra notes $67-75$ and accompanying text. 
back to insertion of early working provisions into the infringement section of patent legislation in the United States and Canada. As discussed further below the Bolar provision was also a focus in the decision by Indian appellate courts to reject linkage. For this reason, the law and policy relating to the Bolar provision is pivotal to the analysis of the effectiveness and efficiency of pharmaceutical linkage as a policy vehicle.

Despite the "scant legislative history" underpinning the linkage regime, ${ }^{64}$ the U.S. Committee on Energy and Commerce (CEC) noted, in its influential report, that the locus of the legal nexus between drug approval and drug patenting under Hatch-Waxman was specifically through the infringement section of patent legislation. In this manner, approval and marketing of generic substitutes was fundamentally linked to patents associated with new and innovative drugs developed by brand pharmaceutical firms. As to which patents were considered relevant to the generic substitute, the CEC stated the law would be aimed at protecting the first product patent per drug or, if there was no product patent, the first process patent. In addition, the CEC recognized that "in some instances" (e.g., situations where there were product and use patents relevant to an existing marketed product as opposed to only a product patent) the listing of multiple patents on the patent register would be foreseeable. ${ }^{65}$

64. Mylan Pharm. v. Thompson, 268 F.3d 1323, 1332 (Fed. Cir. 2001) (noting that the "scant legislative history" did not allow defendants to find congressional intent to create a private action to delist a patent from the Orange Book).

65. H.R. REP No. 98-857, pt. 1, at 22 (1984) (acknowledging that multiple patents would be listed on the patent register to delay generic entry). Specifically, the Committee recognized two different types of patents being properly listed on the patent register. These included

$[A] l l$ product patents which claim the listed drug and all use patents which claim an indication for the drug for which the applicant is seeking approval (hereafter described as a controlling use patent), the applicant must certify, in his opinion and to the best of his knowledge, as to one of four circumstances. ... [T] he Committee recognize[d] that in some instances an applicant will have to make multiple certifications with respect to product or controlling use patents. For example, if the product patent has expired and a valid controlling use patent will not expire for three years, then the applicant must certify that one patent has expired and the other will expire in three years. The Committee intends that the applicant make the appropriate certification for each product and controlling use patent.

Id. (emphasis added). 
The balance of the early working exemption favoring generics gauged against the ability of brand firms to commence legal action prior to generic marketing was viewed by the CEC to "fairly balance" the rights of brand patent owners with those of generic entrants that wish to contest the validity and/or infringement of a patent before such patents expire. ${ }^{66}$ No further protection for brand firms was deemed needed in view of other incentives to firms for innovative drug development.

While allowing for multiple patents to be listed on the register, the CEC nevertheless explicitly noted that the ability of brand firms to delay generic entry using the Hatch-Waxman Amendments should be narrow both in scope and time; the proper time for generic entry being "the expiration date of the valid patent covering the original product" and that "there should be no other direct or indirect method of extending patent term." 67 The extension of patent protection was viewed to be effectively and directly accomplished by Title II of the Hatch-Waxman Amendments allowing for patent term restoration. 68 The standard for listing is that a claim of patent infringement "could reasonably be asserted."69 The legal nexus between drug approval and drug patenting under the Canadian linkage regime also operates through the infringement section

66. Id. at 28. The Committee noted

[T] his additional remedy permits the commencement of a legal action for patent infringement before the generic drug maker has begun marketing. The Committee believes this procedure fairly balances the rights of a patent owner to prevent others from making, using, or selling its patented product and the rights of third parties to contest the validity of a patent or to market a product which they believe is Id. not claimed by the patent.

67. Id. at 46. The Committee elaborated, stating that

Article 1, Section 8, Clause 8 of the Constitution empowers Congress to grant exclusive rights to an inventor for a limited time. That limited time should be a definite time and, thereafter, immediate competition should be encouraged. For That reason, Title I of the bill permits the filing of abbreviated new drug applications before a patent expires and contemplates that the effective approval date will be the expiration date of the valid patent covering the original product. Other sections of Title II permit the extension of the term of a patent for a definite time provided certain conditions are met. There Id. should be no other direct or indirect method of extending patent term.

68. Id. at $17-18$

69. Id. at 31 . 
of relevant patent legislation. ${ }^{70}$ Thus, in order to assess the effectiveness of linkage as a policy lever one must do so through the lens of the Bolar provision as it works in tandem with infringement law and other legislation intended to encourage the development of new and innovative drugs, while also facilitating the timely entry of generic drugs. ${ }^{71}$ For these reasons, linkage legislation balances competing policy interests. ${ }^{72}$

As well described in the literature, the Bolar provision enshrined in the safe harbor provision of Hatch-Waxman ${ }^{73}$ allows "early working" of patented inventions prior to generic entry. While the terms Bolar provision and early working provision are often used conterminously, recent jurisprudence suggests that one may be enfolded within the other and not vice-versa. ${ }^{74}$ As noted by the U.S. Supreme Court in Merck $v$. Integra, the purpose of safe harbor is to protect basic research and development activities that contribute to the generation of information required by drug regulators in order to approve a new drug product. 75 The safe harbor provision can be compared to the Bolar provision, which is more narrowly aimed at facilitating timely generic entry after patent protection for a new product expires. In language reminiscent of that employed by the High Court of Dehli in Bayer v. India to reject linkage, the court in Roche $v$. Bolar denied the request to be exempt from patent infringement proceedings, in order to work-up the generic product ahead of patent expiry. ${ }^{76}$ Shortly after Bolar

70. See generally Biolyse Pharma Corp. v. Bristol-Myers Squibb Co., [2005] 1 S.C.R. 533, para. 33, 58 (Can.) (discussing the procedural steps that must be followed by generic producers pursuant to the Patent Act and the 'patent-specific' analysis necessary to interpret the linkage regulations); AstraZeneca Canada Inc. v. Canada (Minister of Health), [2006] 2 S.C.R. 560, para. 27, 37-39 (Can.) (discussing the obligations of generic manufacturers and the "early working" exception to patent infringement and reinforcing the 'patent-specific' analysis of linkage first established in Biolyse v. BMS, supra.).

71. See Biolyse Pharma Corp., [2005] 1 S.C.R. 533, para. 133.

72. See Id. at para. 133, 189.

73. 35 U.S.C. $\$ 271(\mathrm{e})(1)(2006)$.

74. Merk KGaA v. Integra Lifesciences I, Ltd., 545 U.S. 193, 206 (2005).

75. Id.

76. Roche Prod., Inc. v. Bolar Pharm. Co., 733 F.2d 858, 863-64 (Fed. Cir. 1984). Justice Nichols stated

Bolar argues that even if no established doctrine exists with which it can escape liability for patent infringement, public policy requires that we create a new exception to the use prohibition. Parties and amici seem to think, in particular, that we must resolve a conflict between the Federal Food, Drug, and Cosmetic Act (FFDCA), and the 
was released, however, the U.S. Congress enacted an exception to the patent infringement rule, for uses "reasonably related to the development and submission of information," in order to facilitate timely generic entry by reducing the regulatory lag for bioequivalence testing and regulatory approval. ${ }^{77}$

It is reasonable to speculate that the policy grounds, expected outcomes and outputs, and legal mechanisms underpinning brand and generic drug development pathways do, and indeed should, differ. To begin with, it seems reasonable to state that as a policy vehicle the safe harbor provision extends beyond the scope of Bolar to facilitate generic entry. For example, in the U.S. Supreme Court's decision in Merck KGaA v. Integra Lifesciences, Justice Scalia held that § 271(e)(1) protected all basic research leading up to and "reasonably related" to the process of developing information for a regulatory submission. Justice Scalia noted specifically that the safe harbor provision was not limited in scope to be so narrow as to only support an abbreviated new drug application (ANDA), or generic submission. ${ }^{78}$

Patent Act of 1952, or at least the Acts' respective policies and purposes. We decline the opportunity here, however, to engage in legislative activity proper only for the Congress.

Id. (citations omitted). But see Bayer Corp. v. Union of India, LPA 443/2009, para. 14 (Delhi H.C.) (India) (finding that linkage prevents competition and contradicts public health policy).

77. See Merck KGaA, 545 U.S. at 195. The Court in Merck found, "[i]t is generally an act of patent infringement to 'mak[e], us[e], offe[r] to sell, or sel[l] any patented invention . . . during the term of the patent therefor." Id. (alternations in original). Further, Justice Scalia went on to quote the Federal Food, Drug, and Cosmetic Act:

It shall not be an act of infringement to make, use, offer to sell, or sell within the United States or import into the United States a patented invention (other than a new animal drug or veterinary biological product (as those terms are used in the Federal Food, Drug, and Cosmetic Act and the Act of March 4, 1913) ... . ) solely for uses reasonably related to the development and submission of information under a Federal law which regulates the manufacture, use, or sale of drugs ....

Id. (alterations in original) (quoting the Drug Price Competition and Patent Term Restoration Act of 1984, § 202, 35 U.S.C. § 271(e)(1) (2006)).

78. Id. at 206. The Court stated

The statutory text does not require such a result. Congress did not limit $\S 271(\mathrm{e})(1)$ 's safe harbor to the development of information for inclusion in a submission to the FDA; nor did it create an exemption applicable only to the research relevant to filing an ANDA for approval of a generic drug. Rather, it exempted from infringement all uses of patented compounds "reasonably related" to the process of 
Reading Merck together with Bolar and the HatchWaxman Amendments, it seems that while the safe harbor provision of $\S 271(\mathrm{e})(1)$ is intended to facilitate generic entry, the scope of the provision as an exception to patent infringement is broader and more inclusive; it encourages research and development into both new and generic drugs more broadly. On the one hand, the provision protects research activities on new and innovative therapeutic products from infringement litigation by patent owners in circumstances where such research can reasonably lead to a regulatory submission. ${ }^{79}$ In the absence of such a safe harbor, research of this nature would be chilled to the detriment of both competition and the public. 80 On the other hand, the provision also protects generic firms from infringement while working-up their regulatory submissions. However, it does not necessarily follow that if a certain scope of patents is subject to the safe harbor of $\S 271(\mathrm{e})(1)$ to encourage innovation, an equally broad scope of patents must be included under the linkage umbrella in order to delay generic entry on older drugs.

While Bolar is maintained as legal justification for linkage in the United States, ${ }^{81}$ Canada, ${ }^{82}$ and elsewhere (such as the

developing information for submission under any federal law regulating the manufacture, use, or distribution of drugs. We decline to read the "reasonable relation" requirement so narrowly as to render $\S 271(\mathrm{e})(1)$ 's stated protection of activities leading to FDA approval for all drugs illusory. Properly construed, § 271(e)(1) leaves adequate space for experimentation and failure on the road to regulatory approval: At least where a drugmaker has a reasonable basis for believing that a patented compound may work, through a particular biological process, to produce a particular physiological effect, and uses the compound in research that, if successful, would be appropriate to include in a submission to the FDA, that use is "reasonably related" to the "development and submission of information under ... Federal law."

Id. (internal citations omitted) (alterations in original).

79. See $i d$. at 206-07.

80. See Bouchard, KSR v. Teleflex Part 1, supra note 4, at 243 ("The Solicitor General stated in its KSR brief that SCOTUS jurisprudence stood for the historical proposition that the obviousness requirement is critical to ensure free exploitation of ideas is the rule, to which the protection of a federal patent is the exception."); see also KSR Int'l Co. v. Teleflex Inc., 550 U.S. 398, 419 (2007); Graham v. John Deere Co., 383 U.S. 1, 17-18 (1966); Royal Typewriter Co. v. Remington Rand, Inc. 168 F.2d 691 (2nd Cir. 1948); Whirlpool Corp. v. Camco Inc., [2000] 2 S.C.R. 1067, para. 37 (Can.); Free World Trust v. Électro Santé Inc., [2000] 2 S.C.R. 1024 (Can.).

81. See Merck KGaA, 545 U.S. at 206-07; Mylan Pharm. v. Thompson, 268 F.3d 1323, 1326 (Fed. Cir. 2001)

82. Bouchard, I'm Still Your Baby, supra note 5, at 73-74. 
European Union, India, and Mexico), ${ }^{83}$ the policy grounds have never been elucidated as to how or indeed why infringement law may be properly used to extend beyond early working of $a$ patent on $a$ particular drug, to linkage with many patents on many drugs. ${ }^{84}$ For example, the rationale used to support linkage in Canada was that generic entry would occur on expiry of the "main patent" on a given product. 85 The maximum delay for generic products was claimed to be equal to that for generic approval prior to linkage, or two to three years. ${ }^{86}$ No legal mechanism or policy grounds were offered to prohibit generic entry based on the expiry of multiple patents that relate to the new and innovative drug only distantly in time, particularly the expiry of multiple patents on multiple related drug forms (tablet "following on" capsule form, monohydrate "following on" dihydrate crystalline form, besylate salt "following on" mesylate salt form, enantiomer "following" on racemic mixture, etc.). ${ }^{87}$ Provisions enabling the extension of market exclusivity in this manner only appeared once the regulations accompanying amendments to patent legislation were

83. See generally Final Report, supra note 22, at 122 (July 8, 2009) (noting that a Bolar provision was introduced into the EU regulatory framework in 2004, and that "the research exemption' originally foreseen in the Community Patent Convention as a general exemption from patent infringement for 'acts done for experimental purposes relating to the subject-matter of the patented invention' was widely adopted in the national patent legislations of EU Member States.”); Bayer Corp. v. Union of India, LPA 443/2009, para. 7-8 (the court denied Bayer Corporation's request for the Drug Controller General of India to withhold a drug license to another company, holding that the argument against patent linkage was based on the notion that the entry of generic drugs resulted in saving of expenditure and health costs, and that "[s]uch linkage would undermine the 'Bolar/Early Working' of the patent and deny space for generic medicines.").

84. See Bouchard, I'm Still Your Baby, supra note 5, at 112-13, 115-21.

85. See id. at 120 (the federal government testified to the Parliamentary Committee stating that "a new and innovative drug was said to have "[one] main patent' and 'w[h]en that main patent expires, anyone may copy that product and bring it to market." (quoting Minutes of Proceedings and Evidence of the Legislative Committee on Bill C-91, 34:8 Parliament of Canada, 8:37 (Dec. 1, 1992) (alteration in original)).

86. See id. at 94 ("It is reasonable to speculate however that 'but for' the existence of the linkage regime that generic entry may have occurred closer to expiry of the originating patent or patents ... with an accordingly short period of delayed entry. . . . the linkage regime has proved to be a highly effective mechanism for extending market monopolies on profitable drugs.").

87. See id. at 112-13 (discussing the response to concerns that multiple patents could be listed on the patent register). 
published. 88

The idea that only a "main patent" should be protected is congruent with the statement by the CEC to the effect that the appropriate time for generic entry was the expiration date of the valid patent covering the original product and that there should be no further method of extending patent term. In light of the statement by the Federal Circuit in Mylan that HatchWaxman not only creates the statutory act of infringement but also defines the conditions under which a defense to infringement is available, the number and scope of patents listed on the patent register is crucial to assessing whether the legislation is working consistent with its objective of balancing the competing policy objectives of stimulating innovative research and enhancing generic entry. 89

In light of the above discussion it is somewhat curious that both the courts and (various) government branches responsible for bringing into force the originating linkage regimes in North America have remained largely silent on the policy grounds underpinning the multiple patent listing model, other than to say generally that it fairly balances the rights of brand patent owners with those of generic entrants under certain narrow conditions. 90

Given the lack of policy debate combined with the significant public health implications involved, it is not surprising that some Appellate Courts have taken a dim view of unduly broadening the drug approval-drug patenting nexus, to the detriment of generic entry. The Supreme Court of Canada, in its leading decisions on linkage-Biolyse ${ }^{91}$ and AstraZeneca ${ }^{92}$-narrowly construed its analysis on the breadth of drug submissions and patent listing within the terms of the

88. See id. at 134-35 ("[The] linkage regime has only been in existence for about 25 years following passage of . . . the Canadian NOC regulations in 1993.”).

89. Mylan Pharm. v. Thompson, 268 F.3d at 1331, 1331 n.2 (Fed. Cir. 2001) (stating that the Amendments "were made both to the FFDCA [(the Federal Food, Drug, and Cosmetic Act)] and to Title 35 of the United States Code relating to patents.").

90. See H.R. REP. No. 98-857, pt. 1, at 28 (1984); see also discussion supra note 66 .

91. See Biolyse Pharma Corp. v. Bristol-Myers Squibb Co., [2005] 1 S.C.R. 533 , para. 5 (Can.).

92. See AstraZeneca Can. Inc. v. Canada (Minister of Health), [2004] F.C. 1278, para. 40-41 (Can.). 
Patent Act. 93 The court in AstraZeneca held that under the Notice of Compliance (NOC) Regulations it was necessary to undertake a "patent-specific analysis" rather than a broad inclusive reading of the terms "drug submission" and "patent listing," which would enable the undue prolonging of market exclusivity. ${ }^{94}$ This holding was taken to be consistent with that of the quid pro quo traditional patent bargain. ${ }^{95}$

In Bayer v. India, the High Court of Delhi went one step further, holding that the North American model of linkage, encompassing as it does multiple patents listed per drug or groupings of related drugs, would undermine the early working aspect of Bolar, deny space for generic drugs in the marketplace, and mitigate the positive impact of generic drugs on healthcare expenditures and costs. 96 The court based its decision in part based on the finding that patent linkage is a "TRIPS-Plus" concept and that India had only signed on to TRIPS. Justice Muralindhar noted for the court that "[w]orldwide there is a raging debate on whether patent linkage should be permitted. There is no uniformity in the policy of different countries . . . ."97 Earlier in the decision, Judge Muralindhar noted that there was a growing opinion in developed countries, including the European Union, that cautioned against linkage. ${ }^{98}$

Based on a sort of 'middle way' reading of appellate cases

93. See Patent Act R.S.C. 1985, c.P-4, available at http://laws.justice.gc.ca/PDF/Statute/P/P-4.pdf.

94. See AstraZeneca Can. Inc. v. Canada (Minister of Health), [2006] 2 S.C.R. 560, para. 39 (Can.) ("Given the evident . . . commercial strategy of the innovative drug companies to evergreen their products by adding bells and whistles to a pioneering product even after the original patent for that pioneering product has expired, the decision of the Federal Court of Appeal would reward evergreening even if the generic manufacturer (and thus the public) does not thereby derive any benefit from the subsequently listed patents.").

95. Guidance Document, supra note 52, at 27 (Confirming a "patent specific analysis" relating to the NOC Regulations.). Further, the Canadian government stated that only certain patents are eligible for protection under the NOC regulations, indicating that not all patents fall within the purview of the regulations. Id. at 11; see also Ferring Inc. v. Canada (Minister of Health), [2007] F.C. 300, para. 57 (Can.) (confirming the patent-specific analysis).

96. Bayer Corp. v. Union of India, LPA 443/2009, para. 7 (Delhi H.C.) (India) ("Such linkage would undermine the 'Bolar/Early Working' of the patent and deny space for generic medicines.”).

97. Bayer Corp., LPA 443/2009, at para. 32.

98. Id. at para 7 . 
such as these, one could conclude that the primary problem with pharmaceutical linkage may not be the concept of linkage itself (e.g., balancing generic early working and brand patent protection), but rather the breadth of the legal nexus between drug approval and drug patenting, as well as well as how the regulations operate within the larger system of policy levers, which are intended to stimulate brand and generic drug development. Both issues are dealt with in detail in the discussion that follows.

Figure 1: Therapeutic Product Lifecycle Innovation Incentives

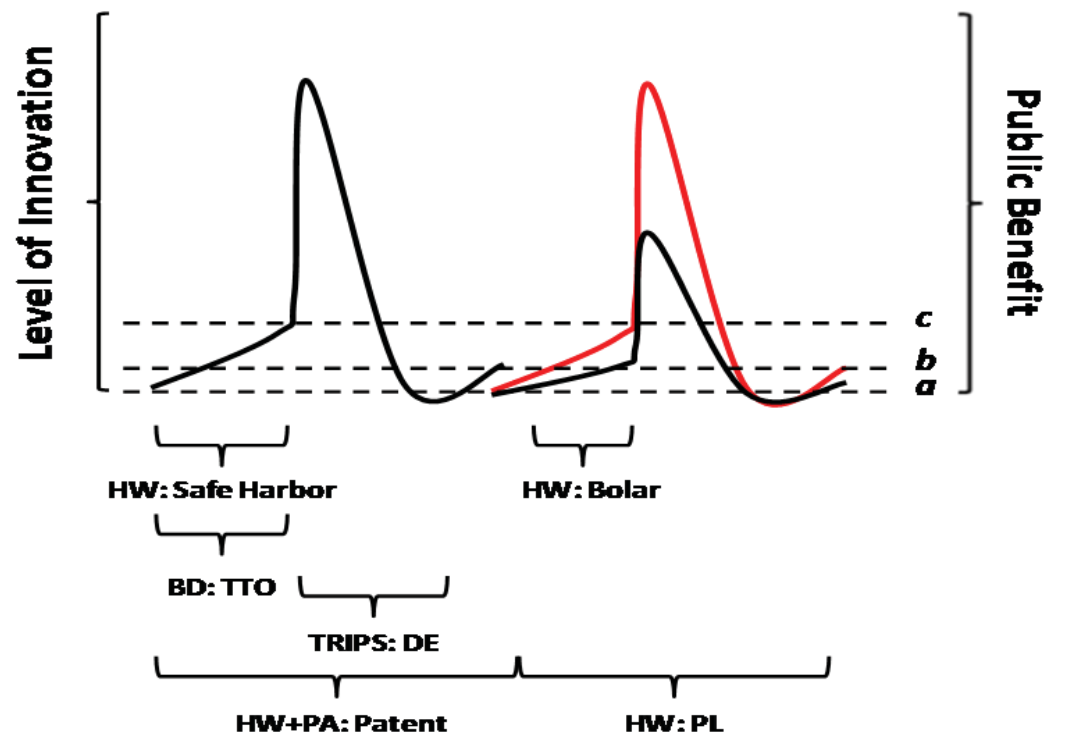

The figure illustrates the complex interrelated legal mechanisms comprising the system of innovation incentives for brand and generic drug development. The left and right $y$ axes are qualitative innovation and public benefit indices. The $\mathrm{x}$ axis represents the product development lifecycle over time. Black waveforms represent the progression of drug development from publicly funded university research to commercialization of medical products by firms (large peak), followed by subsequent genericization (smaller peak). The slow ramp to peak in each case represents the amount of research and 
development necessary to prepare for and obtain regulatory approval. As indicated by the dotted black lines, the degree of innovative research involved in going from baseline (a) to brand products (c) is much greater than that required for generic drugs (b). The red waveform normalizes the generic curve for public benefit owing to price competition. Brand and generic drug development are incentivized at various points in the lifecycle by numerous policy levers, including the broad (research and development) and narrow (Bolar) components of the Hatch-Waxman (Title I) safe harbor provision, patenting by universities and firms stimulated by BayhDole and the traditional patent system, patent term extension under Hatch-Waxman (Title II), data exclusivity for brand regulatory submission packages under TRIPS and other FTAs, and pharmaceutical linkage under Title I of Hatch-Waxman. Time gates for the various policy levers illustrated at the bottom of the figure are not intended to be closed, but rather reflect their general timing in the context of the product development lifecycle.

Figure 1 illustrates the complex system of legal incentives typically employed globally for developing brand and generic drugs, using the United States as an example. This system encompasses a number of interrelated policy-levers, such as traditional patent incentives for firms and universities under patent and Bayh-Dole legislation.99 It also includes the broad research exemption for preclinical and clinical research for originator firms under Title I of Hatch-Waxman, multiple data exclusivity periods for regulatory submissions by originator firms under TRIPS and FTAs (such as NAFTA), and extended patent terms to originator firms to compensate for regulatory delays under Title II of Hatch-Waxman. Additionally, provision is made for extended patent protection for brand firms under the linkage regulation provisions of Title I of Hatch-Waxman for products in later stages of development, and the safe harbor for generic products under Title I of Hatch-Waxman. As indicated by a comparison of the Y-axis data, brand products have a greater level of innovation, entail a greater degree of research and development, and have a broader scope of safe harbor protection than their generic counterparts. The generic products nevertheless have a substantial public welfare benefit, compared to pioneering products, due to their fractional cost. It is worth noting that, notwithstanding the large public welfare

99. For a discussion on the Bayh-Dole legislation, see Bhaven N. Sampat, Patenting and U.S. Academic Research in the 20th Century: The World Before and After Bayh-Dole, 35 RES. POL'Y 772 (2006). 
benefit ascribed to generic drugs, only one of the seven policy levers described in Figure 1 is aimed at facilitating generic entry-the Bolar provision. ${ }^{100}$

It appears reasonable to assume that legal vehicles, such as those depicted in Figure 1, are intended to work together to foster innovation while providing as much public value as possible by facilitating generic entry. ${ }^{101}$ Indeed the Committee on the Judiciary stated in 1984 that the amendments were consistent with the traditional role of Congress to "balance the need to stimulate innovation against the goal of furthering the public interest," in this case increasing the availability of generic substitutes. ${ }^{102}$ However, while the rationale for linking the Bolar exemption to multiple patents listed on the patent register may at one time have been aimed at balance (e.g., a safe harbor abeyance from infringement during the working-up phase to the detriment of patentees, balanced by effective intellectual property protection on innovative drugs in favor of patentees), empirical data that exists at this point suggests the balance effected through this specific legal mechanism may not work as envisioned.

One of the most abundant areas of debate regarding pharmaceutical linkage is whether the provision allowing multiple patents to be listed on the patent register is the main culprit, as opposed to strategic abuse of the automatic stay provision, which is usually singled out as the water thrown on the fire of timely generic entry. ${ }^{103}$ Ironically, in Bolar, litigation was focused on a single patent (relating to the sleep aid flurazepam), rather than a cluster of product, use, route of administration, process, and combination therapy patents, that in turn can be listed on multiple chemical forms of the same original drug. ${ }^{104}$ The conclusion one can draw from this analysis is that the drug approval-drug patent nexus under linkage law should be construed narrowly rather than broadly,

100. See supra notes $67-75$ and accompanying text.

101. H.R. REP. NO. 98-857, pt. 2, at 25 (1984).

102. Id. at 26 .

103. See Caffrey \& Rotter, supra note 8, at 24 ("[T]hrough misapplication of complex regulatory schemes, the FDA process is subject to abuse by parties claiming protections to which they are not legally entitled, and which are, technically, legally impossible."); HORE, PATENTLY ABSURD, supra nota 26, at 3; Avery, supra note 8, at 173; Bulow, supra note 8, at 26.

104. See Roche Prod., Inc. v. Bolar Pharm. Co., 733 F.2d 858, 862 (Fed. Cir. 1984) 
which is consistent with its original purpose in Bolar. ${ }^{105}$

Simply because infringement of one or more patents may be held in abeyance, while a generic company works-up its manufacturing processes prior to regulatory approval, does not justify the grant of prolonged market exclusivity for a cache of older drugs protected by a large group of patents, many of which may be invalid or not infringed by the generic equivalent.106 Moreover, the policy goal of holding patent infringement in abeyance under the safe harbor provision desires that equally strong patents will be associated with the regulatory submission of the party requesting abeyance, and that competing products will be developed. It is reasonable to assume there should be an analogous reciprocity under the linkage regime, as generic products are by nature less innovative, but have substantial social benefits owing to price competition. In light of the foregoing, it seems reasonable to conclude that generic products should not be prevented from gaining regulatory approval by a cluster of follow-on patents that are associated with new and innovative drug products only distantly in time; the original goal of Bolar was to minimize the regulatory lag for generic firms to work-up regulatory submissions and obtain approval. ${ }^{107}$ This can be contrasted to the much more substantial increase in cumulative patent protection that can result from listing multiple weak patents against one or more marketed drugs.

The discussion thus far suggests that it is plausible that provisions in linkage laws allowing multiple patents to be listed against a given drug over time, with little or no requirement for

105. See id. at 863 .

106. See FED. TRADE COMM'N 2002, supra note 11, at viii.

[D]ata in the study suggest that the generic applicants have brought appropriate patent challenges: generic applicants prevailed in nearly $75 \%$ of the patent litigation ultimately resolved by a court decision. ... [and] most generic applicants have waited to enter the market until at least a district court has held that the patent covering the brand-name company's drug product was invalid or not infringed by the ANDA."); HORE, PATENTLY ABSURD, supra note 26, at 5 ("Since 1998 , generic pharmaceutical manufacturers have won at least $75 \%$ of the cases under the Regulations. However, even when the generic firm wins the court cases, the brand-name drug company has successfully extended its market monopoly, sometimes for years after Id. the expiry of the basic patents.

107. See supra notes 
proportional public welfare benefit, represents the weak link in the regulations as they currently operate. This can be argued for two reasons. First, patents may be listed on the patent register as long as they meet statutory listing requirements and are deemed relevant to the marketed drug-relevant being a term that has proven very difficult to legally define. $108 \mathrm{It}$ appears that the relevance requirement can at times be very minimal, ${ }^{109}$ with the effect that often multiple patents are

108. See generally Mylan Pharm. v. Thompson, 268 F.3d 1323, 1327 (Fed. Cir. 2001) ("The Hatch-Waxman Amendments . . . do not include any explicit provisions . . . enabling or prohibiting an action to challenge a patentee's listing of a patent ... the FDA has provided a limited process for disputing the accuracy or relevance of patent information submitted to the FDA ...."). The Court explained that

One who questions the accuracy of the patent information may write to the FDA, and the FDA will request that the applicant confirm the information. ... . [but] '[u]nless the application holder withdraws or amends its patent information in response to FDA's request, the agency will not change the patent information in the list ....

Id. (second alteration in original) (citations omitted) (internal quotation marks omitted). As noted in earlier work by our group, top appellate courts in Canada have wavered substantially on the issue over the last half decade:

Early Federal Court of Appeal jurisprudence in Eli Lilly v. Canada rejected the notion of a strict relevance requirement, opting instead for a narrow statutory reading to the effect that patents need only be relevant to a medicine rather than the drug form specifically approved by regulators. In other words, patents could be listed generally for a drug rather than against a specific drug submission. In 2006, the government issued a Regulatory Impact Analysis Statement (RIAS) accompanying amendments to the NOC Regulations explaining that listed patents were required to contain at least one specific claim to the medical ingredient, formulation, dosage form or use for which approval was granted. This was followed by the decision of the Supreme Court of Canada in AstraZeneca v. Canada, which supported a specific relevance requirement and cast doubt on the reasoning employed by lower courts in defending a general listing requirement. The Federal Court of Appeal, citing AstraZeneca, reversed its earlier ruling that a patent containing a claim for the medicine in a drug is listed generally against the drug, rather than against the specific submission for a notice of compliance upon which the patent list is based. The government issued a revised guidance document in 2009 attempting to harmonize previous jurisprudence and policy grounds supporting a specific listing requirement.

Bouchard et al., Drug Approval-Drug Patenting, supra note 12, at 180-81.

109. See Wyeth Canada v. Ratiopharm Inc., [2008] 1 F.C.R. 447, 462 (Can. Ont. C.A.).

[a] generic drug manufacturer initially may be required to address every patent listed in respect of the Canadian reference product to which the proposed generic version is compared, whether or not the patent is properly listed. If there is an allegation of invalidity or noninfringement, the NOA may lead to a prohibition application and the commencement of the automatic 
listed per drug, particularly for high value pharmaceuticals. ${ }^{110}$ The rationale typically used for this low listing requirement has been that drug regulators are not equipped to assess patents on the register. Ironically, In Bayer v. India, the same rationale was used to reject linkage. ${ }^{111}$

Second, and more importantly, is the fact that multiple patents do not exist in isolation; both in scope and time. They are interconnected to multiple related drugs through weak regulatory submission requirements, ${ }^{112}$ which in turn allow for large numbers of follow-on drugs comprising a temporally evolving cluster of related products and patents. ${ }^{113}$ As a result,

\footnotetext{
24 month statutory stay. However, the generic drug manufacturer may move under paragraph 6(5)(a) of the $N O C$ Regulations for an order dismissing the prohibition application entirely, or dismissing it in relation to the improperly listed patent or patents.
}

Id. See also GUIDANCE DocUMENT, supra note 52, at 7-8 ("[A] patent will be eligible where it is relevant to the drug which is the subject of the submission against which the patent is to be listed. More precisely, the factors for determining the eligibility of a patent submitted with a drug submission," including factors such as "medicinal ingredient," or a "formulation that contains the medicinal ingredient . . . dosage form . . . or use of the medicinal ingredient.") (emphasis added); see also AstraZeneca Can., [2006] 2 S.C.R. 560, para. 39 ("[T] he NOC Regulations require[] a patent-specific analysis, i.e. the generic manufacturer is only required to address the cluster of patents listed against submissions relevant to the NOC that gave rise to the comparator drug ....") (emphasis added).

110. EDWARD HoRE, PATENTly ABSURD, supra note 26, at 20-23 (discussing how brand name drug companies can use different listing strategies to continue evergreening their patents). Dr. Marcia Angell stated that "[n]othing drug companies do is as profitable as stretching out monopoly rights on their blockbusters"). Id. at 21; see also Bouchard et al., Drug Approval-Drug Patenting, supra note 12 (demonstrating empirically that 5\% of granted patents are listed on the patent register for blockbuster drugs); Bouchard et al., Who's Leading Whom, supra note 12 (demonstrating empirically, that while 5\% of granted patents are listed on the patent register on average, the percentage grows substantially with profit such that over 20 patents can be listed and litigated on the most profitable drugs); Hemphill \& Lemley, supra note 13; Hemphill \& Sampat, supra note 13.

111. Bayer Corporation \& Ors. v. Union of India \& Ors. LPA 443/2009 (Dehli H.C.) (India).

112. Cf. Bouchard et al., Drug Approval-Drug Patenting, supra note 12, at 188-90 (describing how the broad scope of regulatory approval for new and follow-on drugs supports the extension of patent monopolies on older blockbuster drugs).

113. Bouchard, I'm Still Your Baby, supra note 5, at 126:

Product clusters are hypothesized to be comprised of an everexpanding number of follow-on drugs centered on a single new and original drug. Products in the cluster are surrounded by a halo of 
originator firms appear to have transferred the thrust of their competitive activities away from competition between each other and towards encouraging competition within their own formulary departments. ${ }^{114}$ The goal of this internal competition appears to be to produce as many follow-on drugs as possible in order to keep generics off market for as long as possible. This has been referred to as portfolio-based innovation, analogous to portfolio financing. ${ }^{115}$ There is no question that portfolio-based innovation is a superb form of innovation from an organizational perspective. The question is, is it desirable from

patents, all of which are interconnected between products within a given cluster. These patents serve two primary functions. First, they provide support for follow-on drug development within in the cluster, and second they provide fodder for listing on the patent register to delay generic entry on the original new and innovative drug. The greater the number of patents permitted to be listed on the patent register and the greater the scope of patent classifications per patent, the greater the ability of patents to support a product cluster and thus to delay generic entry..... Clearly different clusters will have different spatiotemporal characteristics, for example whether they represent clustering within or between brand-name firms or whether there is a single or small number of truly new and innovative drugs per cluster, but the clustering effect of follow-on drugs and associated patents over time remains a central theme.

See generally Bengt DomeIJ, PhaRMECUTICAL PATENTS IN EUROPE (2000) (noting the linkage between the pharmaceutical industry and patent legislation in Europe and how European patent law allows the exclusion of competition for products on a fixed time scale); Bengt Domeij, Initial and Follow-on Pharmaceutical Inventions in Europe, in ECONOMICS, LAW AND INTELLECTUAL PROPERTY 177-98 (Ove Granstrand, ed., 2003) (examining court decisions in Europe and identifying ways in which courts can create extra incentives for valuable follow-on inventions).

114. For a defense of the innovative nature of follow-on drugs, see Joseph A. DiMasi \& Cherie Paquette, The Economics of Follow-on Drug Research and Development Trends in Entry Rates and the Timing of Development 22 PhaRMACOECONOMICS (Supplement 2) 1 (2004); Joseph Di Masi and Laura Faden, Competitiveness In Follow-On Drug R\&D: A Race Or Imitation? 10 NATURE REV. DRUG Discovery 23 (2011). For a rebuttal to DiMasi, see: Aidan Hollis, Comment on The Economics of Follow-On Drug Research and Development: Trends in Entry Rates and the Timing of Development, 23 PHARMACOECONOMICS 1187 (2005).

115. E.g., William Kingston, Intellectual Property's Problems: How Far is the U.S. Constitution to Blame?, 4 INTELL. PROP. Q. 315, 327 (2002) (noting that changes to the U.S. Patent Act in 1952 have created a situation that conduces to the development of a portfolio of patents which allow pharmaceutical companies to spread the risk of research and development across a wide portfolio of related projects under common control). Similarly, Polk and Parchomovsky observed that the right to exclude conferred by a collection of related patents under common control is greater than the sum of individual patents. R. Polk Wagner \& Gideon Parchomovsky, Patent Portfolios, 154 U. PA. L. REV. 1 (2006). 
a social welfare perspective?

In the era pre-dating pharmaceutical linkage, brand pharmaceutical firms typically developed discrete drugs that were associated with one or a small number of patents; once that small number of patents expired, products could be copied.116 In this scheme, pharmaceutical firms were in a similar position to firms in other industries, including those in other technology-heavy sectors. ${ }^{117}$ An argument can be made that this process in turn provided an incentive for competition between brand firms, consistent with judicial articulations of the ends and means underpinning the traditional patent bargain. ${ }^{118}$

A different situation has evolved in the post-linkage era, where loopholes in linkage laws appear to favor a drug development strategy that privileges "product clusters." 119

116. For a review of the relationship of these changes to the multiple patent listing model under linkage, see Bouchard et al., Who's Leading Whom?, supra note 12; Bouchard, Still Your Baby, supra note 5. For a review of "technology-specific" patent law, see Dan Burk \& Mark A. Lemley. Is Patent Law Technology Specific?, 17 Berkeley Tech. L.J. 1155, 1157-1208 (2002).

117. For a review of major changes in United States and global patent law since 1952 and the impact of these changes on patent portfolios and drug development, see Kingston Id and Stuart Macdonald, When Means Become Ends: Considering the Impact of Patent Strategy on Innovation, 16 Info. Econ. \& Pol'y 135 (2004).

118. For analysis of balancing patent law and competition law in U.S. appellate jurisprudence, see, for example, KSR Int'l Co. v. Teleflex, Inc., 550 U.S. 398, 419 (2007) (noting that in many modern fields, market demand drives design trends); Graham v. John Deere Co., 383 U.S. 1, 17-18 (1966) (remarking that the rapid advance of technology requires patent holders to be aware of these conditions within the context of judicial standards); Hotchkiss v. Greenwood 52 U.S. (11 How.) 248 (1850); Royal Typewriter Co. v. Remington Rand, Inc., 168 F.2d 691 (2d Cir. 1948) (describing the balance between disclosure of the invention for gain to the inventor and the potential for others to take advantage of the discovery without benefit to the original inventor). For a parallel analysis in Canadian jurisprudence, see, e.g., Whirlpool Corp. v. Camco Inc., [2000] 2 S.C.R. 1067, para. 37 (Can.) (describing the bargain between patentee and the public, which requires protection of the patent holder in exchange for the disclosure of the invention with the agreement of the public to not allow an extension of the patent beyond a certain term of years); Free World Trust v. Électro Santé Inc., [2000] 2 S.C.R. 1024, para. 13 (Can.) ("In return for disclosure of the invention to the public, the inventor acquires for a limited time the exclusive right to exploit it.”).

119. See generally Bouchard et al., Drug Approval-Drug Patenting, supra note 12 , at 176-83 (describing the development of linkage regulations in the United States and Canada and product how the interaction of linkage law 
Product clusters are hypothesized to be comprised of an expanding number of follow-on drugs evolving from a single new and original drug, surrounded by a constellation of patents, which interconnect products within a given cluster through a combination of traditional infringement law and the listing provision under emerging linkage law. ${ }^{120}$ These patents serve two different yet vital functions. First, they provide support for follow-on drug candidates via traditional infringement law, and second they provide fodder for listing on patent registers to delay generic entry under linkage law. Perhaps most important for policy-makers may be the sum of the interactions between multiple drugs and multiple patents in these clusters that most effectively chills generic entry.

Given that empirical data are only beginning to be reported on pharmaceutical linkage, this clustering effect may present a more substantial barrier to generic entry than previously recognized and it is not clear whether generics are being adequately compensated for taking on the risk of litigation. ${ }^{121}$ Our work thus far suggests this conclusion may apply more strongly in jurisdictions where litigation under linkage regulations does not constitute final decision, where linkage laws do not provide generic entrants with an

with patent law and food and drug law may conduce to the development of product clusters). For an articulation of the product cluster hypothesis, see generally RON A. BOUCHARD, PATENTLY INNOVATIVE: HOW PHARMACEUTICAL Firms Use EMERging PATENT LAW TO EXTEND MONOPOlies ON Blockbuster Drugs (Biohealthrare Publishing Series on Pharma, Biotech AND Bioscience: Science Technology) (ForthCOMing 2011) (Chapter 7 describes how linkage regulations have impacted the pharmaceutical industry in recent years and provides a "path of least resistance' to the development of product clusters); Bouchard, I'm Still Your Baby, supra note 5; Bouchard et al., Drug Approval-Drug Patenting, supra note 12. The term "patent clusters" has been used by the E.C. in its "Originator-Generic Competition" Fact Sheet accompanying the EC Sector Pharmaceutical Sector Preliminary Report, where it was stated that a common strategy employed by brand firms to maintain revenue streams from blockbuster drugs for as long as possible is the creation of "patent clusters" by the filing of numerous patents for the same medicine. As noted in the report, evidence obtained by the Commission from inspections of originator companies revealed that the objective of the clustering strategy was to delay or block the market entry of generic medicines.

120. See supra note 119

121. Merck \& Co. v. Apotex Inc., [2010] 2 F.C.R. 389, para. 101-02 (Can.); For a discussion of the issue of generic compensation, see generally Aiden Hollis, Generic Drug Pricing and Procurement: A Policy for Alberta, SPS RES. PAPERS (Feb.

2009), http://www.iapr.ca/files/iapr/Hollis\%20on\%20line\%20final\%20Feb\%203.pdf. 
exclusivity period for first movers compared to those that do not, where the relevance requirement for patent listing is comparatively weak, where patents are comparatively easier to obtain, where linkage law allows for settlements between brand and generic firms to restrain competition in the 180 day first mover period, and where the evidentiary standard for the approval of new and follow-on drugs is comparatively low.

Evidence reviewed to this point suggests the Bolar provision was narrowly intended to encourage generic entry. Evidence that this narrow exception to patent law was ultimately in service of a short-term exemption that favors, not restricts, competition can be found in the words of the CEC to whom the Hatch-Waxman bill was referred:

The purpose of sections 271(e)(1) and (2) is to establish that experimentation with $a$ patented drug product, when the purpose is to prepare for commercial activity which will begin after $a$ valid patent expires, is not a patent infringement. . . Article 1, Section 8, Clause 8 of the Constitution empowers Congress to grant exclusive rights to an inventor for a limited time. That limited time should be a definite time and, thereafter, immediate competition should be encouraged. For that reason, Title I of the bill permits the filing of abbreviated new drug applications before a patent expires and contemplates that the effective approval date will be the expiration date of the valid patent covering the original product. Other sections of Title II permit the extension of the term of a patent for a definite time provided certain conditions are met. ${ }^{122}$

According to this argument, evergreening 123 of older products via multiple patent listing is contrary to the objective of Hatch-Waxman to facilitate generic entry via a short-term suspension of patent infringement and competition.

The Committee on the Judiciary (COJ), to whom HatchWaxman was also referred, acknowledged that FDA rules restricting generic entry prior to Hatch-Waxman "had serious anti-competitive effects" and that the "net result of these rules has been the practical extension of the monopoly position of the patent holder beyond the expiration of the patent."124 The COJ went further as regards the multiple patent listing issue, stating:

The first amendment rejected by the Committee was offered by Mr.

Hughes. The Hughes amendment would have permitted the granting

122. H.R. REP. No. 98-857, pt. 1, at 45-46 (1984) (emphasis added).

123. See supra note 47.

124. H.R. REP. NO. 98-857, pt. 2, at 4 (1984). 
of a patent term extension for the substances regulated by the bill for each regulatory review period. The net result of the amendment was to permit multiple patent term extensions on what was essentially the same drug product. This amendment was supported by the Patent and Trademark Office (PTO). The PTO argued that the version of H.R. 3605 reported by the Committee on Energy and Commerce would create two different types of patents for drugs; those which are extendable and those which are not extendable. The latter category, they claim, includes subsequent use, method and composition patents.

The Committee considered these arguments and rejected them for two reasons. First, the Committee accepted the rationale put forward by the Committee on Energy and Commerce concerning the need to avoid multiple patent term extensions. Our sister Committee argued that the only patented product which experiences any substantial regulatory delay is the first product patent (or if there is no product patent, the first process patent). Therefore, they reason that subsequent patents on approved drug products are frequently not the same magnitude of innovation as occurs with respect to the initial patent. Thus, the Committee on Energy and Commerce concluded on public policy and health policy grounds that only the first patent on a drug-type product should be extended. ${ }^{125}$

In making these comments, the COJ stated in plain and unambiguous terms that patent extension on weakly innovative products was contrary to public policy and health policy grounds. ${ }^{126}$ The specific mention of the "first product patent" parallels comments made in the parliamentary debate in Canada prior to linkage coming into force that generic entry would occur on expiry of the "main patent" on a given product, 127 not on expiry of a cluster of patents. This statement is coherent with that of the CEC to the effect that the appropriate time for generic entry is the expiration date of the valid patent (or patents) covering the original product and that the Hatch-Waxman Amendments do not contemplate any other method of extending patent term. ${ }^{128}$

Later in its report, the COJ was more explicit as to what public policy grounds were involved, stating that early generic availability would substantially "assist in the reduction of health care costs. . . these reductions will be especially important to the poor, the under-insured, and the elderly." 129 The government as a purchaser of prescription drugs was also deemed to benefit substantially by the amendments. The COJ

125. Id. at 7-8 (emphasis added).

126. Id.

127. See Bouchard, I'm Still Your Baby, supra note 5, at 50.

128. See supra text accompanying note 122 .

129. H.R. REP. NO. 98-857, pt. 2, at 25 (1984). 
also stipulated that given the regulatory nature of the industry involved, early working allowing a shortening of the delay of generic entry between eighteen and twenty-four months would not unduly encroach on the patent rights of brand firms and thus properly enhanced competition between brand and generic firms. ${ }^{130}$ This is consistent with the statement of the Federal Circuit in Mylan, to the effect that the Hatch-Waxman Amendments were intended to balance two competing policy goals and that this balancing function was achieved by establishing a generic drug approval procedure at one end of the balance and restoring patent terms for pioneer firms to make up for lost time during the regulatory approval stage at the other end.131 No mention was made of creating a second back-end process for evergreening older drugs.

While it may not have been anticipated at the time linkage came into force in either originating jurisdiction, and bearing in mind the COJ's statement that up to Bolar, Congress "has never had occasion to evaluate the competing policy considerations presented by this bill," 132 the empirical data that have been reported in countries with longer standing linkage regulations, such as the United States and Canada, suggest that the multiple patent listing mechanism has grown to be sufficiently unwieldy that the outputs of the system (delayed generic entry and anti-competitive effects) maybe in increasing conflict with the twin policy goals underpinning both Hatch Waxman and the NOC Regulations. That is, that permitting multiple patent listings on an array, or cluster, of related drug products may yield a system which behaves in precisely the same manner said by the COJ to offend public policy and health policy grounds. 133

There have been numerous suggestions in case law and government reports that the multiple patent listing models was adopted because food and drug agencies such as the FDA, Health Canada, and others, did not, and indeed do not, have the expertise to judge patent validity and/or infringement. This

130. Id. at 29 (1984) ("As a result . . generic drugs will be able to be placed on the market between 18 months and 2 years earlier than without this provision.").

131. Mylan Pharm. v. Thompson, 268 F.3d 1323, 1326 (Fed. Cir. 2001) (quoting H.R. REP. No. 98-857, pt. 1, at 14 (1984)) .

132. H.R. REP. NO. 98-857, pt. 2, at 29 (1984).

133. See supra notes 124-130 and accompanying text. 
sentiment was echoed in the recent Bayer v. India decision.134 The court held that drug regulators were "plainly not equipped to deal with issues concerning the validity of a patent" and that to oblige regulators to do so would be inconsistent with their mandate as regulators and the private law function of domestic Indian patent legislation. ${ }^{135}$ Indeed, amendments linkage law pertaining to patent listing in jurisdictions such as the United States and Canada that have been interpreted by some to be successful ${ }^{136}$ may be less so than recognized in the long run, if only because they have been too far downstream to be truly effective. In other words, the amendments have been aimed at fixing automatic stay abuses even though the antecedent problem that gives rise to these downstream abuses is that of multiple patent listing, particularly in relation to product clusters. As discussed above, this reasoning was employed in Bayer to deny linkage of food and drug law to patent law through the infringement section of India's patent legislation. ${ }^{137}$

A mechanism for oversight of patent listing that may be both more efficient and more effective than policing by the courts or drug regulators may be to create a separate administrative body within the mandate of the Patent and Trademark Office (PTO) to independently assess patents for relevance to new and innovative drugs prior to listing, as occurs in some jurisdictions with regards to drug price controls. Similar arm's length institutions have been created to police

134. Bayer Corporation \& Ors. v. Union of India \& Ors. LPA 443/2009 (Dehli H.C.) (India), at para 28

135. Id.

136. See generally Epstein \& Kuhlik, supra note 8, at 14 (arguing that the gains from biomedical innovation outweigh the barriers presented by the "anti-commons" and that Hatch Waxman has been a positive, rather than negative, vehicle for development of the generic drug industry in the United States). But see Avery, supra note 8, 196-200 (declaring the Medicare Modernization Act, which was passed to alleviate the abuses of the HatchWaxman Act by pharmaceutical patent holders, had been unsuccessful in achieving that goal); Hemphill and Lemley, supra note 13 (noting that Hatch Waxman is not working as intended because pharmaceutical patent owners have responded with a "sophisticated program of product "lifecycle management," which is code for finding ways to extend exclusivity as long as possible”.).

137. Bayer Corp. v. Union of India, LPA 443/2009, para. 22 (Delhi H.C.) (India) ("In granting marketing approval to a patented drug, the D[rug] $\mathrm{C}$ [ontroller] G[eneral of] $\mathrm{I}$ [ndia] is by no means itself infringing upon any patent or abetting the infringement of any patent by the applicant in whose favor the marketing approval is being granted.") (alteration in original). 
drug prices in Canada (Patented Medicines Prices Review Board, or PMPRB) 138 and to facilitate translational research and innovative drug development in the United States (National Center for Advancing Translational Sciences), 139 and to guide the use of health technologies, clinical practices, and health promotion based on considerations of efficacy and costeffectiveness in the United Kingdom (National Institute for Clinical Excellent, or NICE). ${ }^{140}$

An alternative to an independent advisory board would be to develop a qualitative innovation index for assessing the social value of pharmaceutical products and related patents. Where an index of this nature is grounded in regulatory preferences for new and follow-on drugs expressed by regulators themselves, it could be used to determine which patents should be listed on the patent register. ${ }^{141}$ Such an index might, to a significant degree, side-step some of the criticism of regulatory agencies for lacking expertise as to patent quality. ${ }^{142}$ This is because the selection at issue would be grounded in regulatory preferences expressed by public health agencies exercising their mandate to set the evidentiary benchmarks relating to benefit versus risk, unmet medical need or significant advance in therapeutic value. Decisions of this nature, unlike those relative to patent validity, are within the expertise and mandates of health agencies such as the FDA, Health Canada, and the European Medicines Agency.

Finally, we note that there may be subtle but significant cultural differences between jurisdictions as to the tendency of both brand and generic firms to game the system and the reaction of the public and government when the system is

138. Patented Medicine Prices Review BoARd (last visited April 18, 2011), http://www.pmprb-cepmb.gc.ca/english/home.asp?x=1.

139. Gardiner Harris, A New Federal Research Center Will Help to Develop Medicines, N.Y. TIMES, Jan. 23, 2011, at A1.

140. NATI'L INST. FOR HEALTH \& CliniCAL EXCELlENCE, http://www.nice.org.uk/ (last visited June 13, 2011).

141. Ron A. Bouchard, Qualifying Intellectual Property II: A Novel Innovation Index for Pharmaceutical Products (unpublished manuscript) (on file with author), available at http://papers.ssrn.com/sol3/papers.cfm?abstract_id=1809817.

142. See, e.g., Applications for FDA Approval to Market a New Drug: Patent Submission and Listing Requirements and Application of 30-Month Stays on Approval of Abbreviated New Drug Applications Certifying That a Patent Claiming a Drug Is Invalid or Will Not Be Infringed, 68 Fed. Reg. , 36,676, 36,683 (June 18, 2003). 
effectively gamed. Jurisdictions such as the United States that are viewed by some to have more of an arm's length relation between government and industry and be comparatively more litigious in seeking legal remedies, ${ }^{143}$ may exhibit faster and more efficient adaptive responses than jurisdictions with more cooperation between government and industry. As indicated by the rapid and strong responses of nations such as India ${ }^{144}$ and Australia 145 to the push for linkage in those jurisdictions compared to the more receptive responses of nations such as Canada, Mexico, and South Korea, it is possible there are significant cultural differences in the manner in which linkage is accepted or refuted and, when it is accepted, the speed and strength of adaptive responses by law-makers when the system is acknowledged to list to one side and require correction. A similar conclusion may be drawn with regard to the comparative responses of the public and governments of the United States and Canada in response to perceived abuses of the automatic stay provision.

The goal of further research on original policy intent will be to obtain empirical qualitative and quantitative data to determine whether or not multiple patents listed per drug provide the linchpin for a potential clustering effect of this nature. As revealed by the recent E.C. Pharmaceutical Sector Inquiry, the Bolar debate is far from over: some originator firms are claiming that by permitting marketing authorization before a patent dispute has been settled, "the authorities willingly collude in the alleged patent infringement". ${ }^{146}$ The

143. Wiktorowicz, supra note 30, at 643 (describing the conflict resolution process between industry and the government in the United States as involving public hearings and redress through the courts and how this differs from the degree of public-private partnership between government and industry in Canada, the United Kingdom and France).

144. See infra text accompanying notes $173-180$

145. See infra text accompanying notes 164-165.

146. Final Report, supra note 22, at 315.

Certain originator companies allege that by granting marketing authorisation, the authorities willingly collude in the alleged infringement. These originator companies therefore argue that no marketing authorisation should be granted until the allegation of patent infringement has been settled. Occasionally, actions are accompanied by a threat to sue the marketing authorisation body for Id. damages if marketing authorisation is granted."

As long as these activities are strictly necessary to prepare for an MA application, they are not deemed to infringe patents rights ... for medicinal products in view of the so-called Bolar provision. This 
argument is not persuasive, but nonetheless may carry weight with some regulators.

\section{B. LEGAL CHECKS AND BALANCES}

In addition to identifying the original policy intent for linkage, it is also important to map the system of legal checks and balances in different linkage regimes and investigate how they operate together to determine the outputs of the system. The specific basket of checks and balances in a given linkage regime is vital, as it determines not only how a complex system of pharmaceutical regulation begins operating de novo following the coming into force of law but also how it evolves over time to yield demonstrable empirical results. It has been shown, for example, that the behavior of dynamic legal systems, ${ }^{147}$ including how systems learn, self-regulate, adapt and grow, 148 is strongly influenced by positive and negative feedback. ${ }^{149}$ Positive feedback results in growth or amplification of a particular process or group of related processes whereas negative feedback results in tamping or slowing of a particular process or group of processes. Studies of complex social, biological, and technological systems have shown that the unintended consequences resulting from feedback have the potential to force a system away from operating at or near the point of efficiency. ${ }^{150}$

provision, which was introduced by Directive 2004/27, creates a safe harbour for certain tests and studies while the reference product is still patent-protected so as to enable the generic producer to apply for marketing authorisation once the eight-year period of data exclusivity granted to the holder of the original MA has elapsed.

Preliminary Report, supra note 22, at 260.

147. Cf. JERVIS, supra note 38 (discussing complexity in political and social spheres); Harrison, supra note 9, at 473-77 (describing the complex adaptive and dynamic nature of world politics).

148. Cf. Ruhl 2005, supra note 42, at 34-39 (addressing environmental regulation and arguing that adaptive management regulation is the only way to successfully address present and future legal, environmental problems). See generally J.B. Ruhl, The Fitness of Law: Using Complexity Theory to Describe the Evolution of Law and Society and its Practical Meaning for Democracy, 49 VAND. L. REV. 1407 (1996) (utilizing Complexity Theory, a study in the change of dynamical systems, to examine how the law unfolds).

149. See generally note 43 and accompanying text.

150. See, e.g., Robert M. May et al., Complex Systems: Ecology for Bankers, 451 NATURE 893 (2008) (comparing the financial system to complex adaptive 
In the case of linkage regulations, unchecked feedback could yield an array of results that move the system away from its intended consequences. For example, even though the original policy intent was to balance production of new and innovative drugs with timely generic entry, a poorly operating system could yield a decline in innovative products despite strong patent protection; substantial delays in generic entry despite abbreviated procedures for approval; increased monopoly pricing despite incentives for innovation; wasteful litigation despite abbreviated approval and litigation processes; and increased, rather than decreased, public health costs. Results such as these could be the consequence of a system with insufficient checks and balances that is driven to certain outputs much like damage to one wheel forces a car to inevitably list to one side.

An example of feedback with unintended consequences is provided for by the automatic stay, which is a fundamental feature of pharmaceutical linkage. Studies in both North America jurisdictions where linkage originally came into force have demonstrated that that the likelihood of further patent listing and litigation on high value drugs increases substantially when a brand firm experiences success with its first stay. 151 Given the automatic nature of the injunction, generics can be kept off market with comparatively less risk to

ecosystems and noting the need to identify conditions that make dynamic systems unstable). For a look at the role of feedback in policy failure, see generally JERVIS, supra note 38 (complex political systems); Ron A. Bouchard, Reflections on the Value of Systems Models for Regulation of Medical Research and Product Development, 17 Health L. REV. 28 (2008) (discussing the purposive systems-based policy development process in the health law area); Ron A. Bouchard, KSR v. Teleflex Part 2: Impact of U.S. Supreme Court Patent Law on Canadian and Global Systems-Based Innovation Ecologies, 15 HEALTH L. J. 247 (2008) (discussing the impact of the U.S. Supreme Court's decision in KSR v. Teleflex on global innovation ecologies through the conceptual framework of complex adaptive systems); Bozeman, supra note 38 (efficient markets); Bozeman \& Sarewitz, supra note 38 (science policy); Harrison, supra note 9 (complexity in international politics); Sterman, supra note 38 (reflections on the development and utility of systems science and discussing the claim that as a result of fundamental uncertainty "all models are wrong").

151. See, e.g., FED. TRADE COMM'N, supra note 11, at 13-21 (studying the litigation tendencies of brand-name companies taking action against generic companies in the first and second instances of alleged infringement); HoRE, PATENTLY ABSURD, supra note 26, at 6-9 (noting that Canada's patent regulations tie up generic manufacturers in litigation thus delaying entry of generic drugs). 
brand firms. ${ }^{152}$ As noted by the Federal Court of Canada, which exclusively hears patent matters under the NOC Regulations, "by merely commencing the proceeding, the applicant obtains what is tantamount to an interlocutory injunction for up to 30 months without having satisfied any of the criteria a court would require before enjoining issuance of an NOC."153 As widely noted, governments in both the United States and Canada have had to step in to amend their respective linkage regimes in order to curb various abuses of the automatic stay provision.

The delay of generic entry owing to abuses of the automatic stay is just one example of unintended consequences of legislation that occur as a result of adaptation by firms as they gain experience with the system of legal checks and balances that comprise a particular linkage regime. Our work has identified a number of differences in the system of checks and balances employed by different jurisdictions. It also suggests that feedback between these mechanisms can strongly influence the output of the system on brand and generic drug availability and costs. For example, the U.S. Hatch-Waxman regime provides generic firms with the opportunity to earlywork an invention without infringing brand patents (Bolar) as well as to indirectly rely on the data in the branded company's application to support a generic company's application for approval. 154 These benefits are balanced, however, by the automatic stay of thirty months in favor of brand firms, which can be shortened or lengthened at the discretion of a court. ${ }^{155} \mathrm{~A}$

152. In the United States, the risk is also minimized for generics, who can resolve patent issues without risking damages incurred in marketing the drug and then being sued for infringement. This is not the case in Canada, as proceedings under linkage laws are summary in nature and can, and often are, followed by full infringement proceedings. A recent study of litigation in the European Union revealed that even when disputes are few in number, they exert a strong chilling effect on generic entry as a result of the mere risk of interim injunctions. Final Report, supra note 22, at 200. The data showed that over half of proceedings against generics were preceded by prior disputes, leading the authors to conclude the chilling effect of even a small number of proceedings "illustrates the strength of the link between patent-related exchanges and patent litigation." Id. at 209.

153. Bayer AG v. Canada (Minister of National Health \& Welfare), [1993] 51 C.P.R. (3d) 329, para.13 (Can.).

154. Drug Price Competition and Patent Term Restoration Act, 21 U.S.C. $\S 355(2006)$.

155. Id. 
court's early determination of patent invalidity or noninfringement will necessarily cut the thirty month period short. On a secondary level, the thirty month stay preventing generics from entering the market is balanced by 180 day period of marketing exclusivity for the first entrant ${ }^{156}$ where generic prices could escalate in absence of further generic competition. The intent of this 180 day exclusivity period is to provide an incentive to challenge patents. ${ }^{157}$ This series of legal checks and balances should in theory minimize strong positive feedback in favor of either brand or generic firms, and works towards balancing the interests of both parties as well as the competing policy goals involved. ${ }^{158}$ In practice there has been significant gaming of the automatic stay which has led to frequent settlements between generics and brands, and frequent amendment of linkage laws. ${ }^{159}$

Unlike the United States, Canada had a significant generic industry prior to the linkage regime. Repeal of compulsory licensing and the coming into force of the NOC Regulations was also intended to balance the competing interests of brand and generic drugs and to effect cost savings for consumers. ${ }^{160}$ As in the United States, both a Bolar provision and thirty month stay (now reduced to twenty-four months) were provided under the linkage regime.161 However, unlike the United States, the automatic stay in Canada was not balanced by any exclusivity period for generics, and the incentives for generic entry are comparatively weak.162 At the same time, generic firms are limited in the damages they can collect if they are excluded from the market on the basis of brand litigation on an invalid patent. 163 Moreover, unlike the U.S. regime, proceedings under

156. Id.

157. See generally Mossinghoff, supra note 8, at 188-89 (chronicling the legislative history of the Hatch-Waxman Act including the rationale behind its passage).

158. Id.

159. See FED. TRADE COMM'N, supra note 11, at ii-xi (recommending fixes to alleviate the gaming by the pharmaceutical industry); see also FEDERAL Trade Commission, PAY-For-DElay: How DRUg COMPANY PAY-OFfs COST CONSUMERS BILLIONS 4-6 (2010) (noting findings of the FTC that numerous final agreements delayed generic entry).

160. See supra note 5.

161. Patented Medicines (Notice of Compliance) Regulations, SOR/1993133 (Can.).

162. See Hollis, supra note 121, at 34 .

163. See Merck \& Co. v. Apotex Inc., [2010] 2 F.C.R. 389 (Can.); Apotex Inc. v. Merck \& Co., [2009] 3 F.C.R. 234 (Can.). 
the NOC Regulations are summary in nature and do not constitute a final decision on issues of validity or infringement. Thus, even under circumstances where a generic has obtained a finding of invalidity or non-infringement on all relevant listed patents, it is still vulnerable to a traditional infringement action on the exact same patents. By contrast, the provision for generics to challenge patents prior to marketing and to eliminate the threat of infringement is a prime mechanism by which the U.S. Hatch-Waxman regime is seen to foster generic entry. Were it not for the combination of both mechanisms, linkage would operate only as a type of advisory option given the vulnerability of generic firms to double-jeopardy type litigation. Therefore, unlike the U.S. regulations, the specific system of legal checks and balances inherent to the Canadian linkage system may provide for greater legal uncertainty and, unintentionally, favor brand pharmaceutical firms. ${ }^{164}$

Australia, by contrast, seems to have learned and adapted well from these experiences. Australian trade negotiators, for example, included in the domestic linkage regime specific provisions against evergreening and a provision for evidencebased assessment of pharmaceutical innovation despite opposition from American negotiators. ${ }^{165}$ Analogous to the U.S. regime, this provision has been balanced by more recent changes to domestic formulary law mandating price controls for generic drugs under certain circumstances. Similar to Australia, India's patent legislation also contains an express provision against evergreening, which has been challenged unsuccessfully by brand firms as being non-compliant with TRIPS. 166 Thus, it can be seen that different legal mechanisms (structure) can impact substantially on the outputs of the linkage system (function) in different jurisdictions.

164. See Hollis, supra note 121, at 8-10.

165. Thomas Faunce et al., Assessing the Impact of the Australia-United States Free Trade Agreement on Australian and global Medicines Policy, GLOBALIZATION \& HEALTH (Oct. $\quad 6, \quad$ 2005), http://www.globalizationandhealth.com/content/1/1/15. India's patent legislation also contains a provision against evergreening, which has been challenged unsuccessfully by brand firms as being non-compliant with TRIPS. Indian Patents Act, No. 39, Section 3(d) of 1970, INDIA CoDE (1970). For a description of Indian patent law in the context of pharmaceuticals, see generally FEROZ ALI KHADER, THE LAW OF PATENTS-WITH A SPECIAL FOCUS ON PHARMACEUTICALS IN INDIA (2007).

166. See supra note 165 and accompanying text. 
Jurisdictions that are contemplating bringing in some form of linkage in the future would do well to heed the lessons learned by jurisdictions with older forms of linkage.

\section{Convergence of Public Health and Economic Policy}

The original policy intent to balance the competing goals of stimulating pioneering innovation and facilitating generic entry through the same legal nexus necessarily implies a certain degree of policy disharmony. The first of these goals is aimed primarily at private gain while the other is to benefit the public in the form of lower government expenditures and/or lower costs to consumers. While in practice both brand and generic firms seek to increase market share for their own ends, the goal of cost savings renders increased generic availability an important public health issue. ${ }^{167}$ This has not gone unnoticed by the Supreme Court of Canada in its assessment of the nation's linkage regime. ${ }^{168}$ Similar observations have been made by the U.S. Supreme Court.169 It is clear in both jurisdictions that convergence of public health and economic policy has been embraced, however reluctantly, in the form of the linkage regime as well as other legislation relating to prioritization and commercialization of publicly funded medical research. ${ }^{170}$ For example, in AstraZeneca $v$. Canada, the Supreme Court of Canada recently held that pharmaceutical linkage lies "at the intersection of two regulatory systems with sometimes conflicting objectives." 171 Whereas food and drug law seeking to ensure the safety and efficacy of new medications before they can be put on the market, patent law provides private inventors with exclusive right to exploit their invention for a period equal to the patent term. Regarding the convergence of public health and economic, or industrial, law,

167. See Comm'n on the Future of Health CARe in Canada, Building ON VAlues: The Future OF HeAlth CARE IN CANADA 189-91 (2002). Senator Hatch, at the time the Hatch-Waxman Act came into force, said "[t]he public receives the best of both worlds-cheaper drugs today and better drugs tomorrow." Epstein \& Kuhlik, supra note 8, at 11.

168. AstraZeneca Can. Inc. v. Canada (Minister of Health), [2006] S.C.R. 560 (Can.); Bristol-Myers Squibb Co. v. Canada (Attorney General), [2005] 1 S.C.R. 533 (Can.); Merck Frosst Can. Inc. v. Canada (Minister of National Health and Welfare), [1998] 2 S.C.R 193 (Can.).

169. Eli Lilly \& Co. v. Medtronic, Inc., 496 U.S. 661, 676-79 (1990).

170. KRIMSKY, supra note 3, at 177-82; see supra Figure 1.

171. AstraZeneca Can. Inc. v. Canada (Minister of Health), [2006] S.C.R. 560, at para. 12 (Can) 
the court noted that until linkage came into force the two regulatory systems were largely kept "distinct and separate."172

Other jurisdictions, however, have not heeded the siren call of convergence. For example, in the recent High Court of Delhi Bayer decision, the court rejected linkage specifically on the grounds of convergence. ${ }^{173}$ Justice Muralidhar, speaking for the Court, stated that the legislative schemes for patent law and drug approval are "distinct and separate" and that the attempt to establish a linkage between the two cannot be countenanced. ${ }^{174}$ The court noted that in granting approval for generic equivalents, drug regulators neither per se infringe the patent rights of brand firms nor abet the infringement of such rights by generic firms simply because the drug is patented. 175 In rendering its decision, the court noted that given the presumption of validity for patents associated with the drug for which marketing approval is sought, linkage would improperly oblige drug regulators to enforce the rights of owners under patent legislation, which is not the function of the regulator. ${ }^{176}$ The court held that such action was in the private law domain, and that when a private right is conferred by a statute such as under domestic patent legislation, the proper remedy for an infringement of that right must be in terms of that statute and no other. 177 The court noted that the expectation is that the

\footnotetext{
172. Id.

173. Bayer Corp. v. Union of India, LPA 443/2009 (Delhi H.C.) (India).

174. Id. para. 28. Justice Muralidhar stated

This Court concurs with the learned Single Judge that the scheme of both the Patents Act and the DCA are distinct and separate and that the attempt by the appellant Bayer to establish a linkage cannot be countenanced. ... What Bayer wants the DCGI to do is to enforce its rights as a patent holder in terms of Section 48 of the Patents Act. That is plainly not the function of the DCGI. His powers and jurisdiction are circumscribed by the DCA and not the Patents Act. It is entirely up to the patent holder to seek whatever remedies are available to it to enforce and protect its patent from infringement. This is in the private law domain. The DCA has nothing to do with it. There is merit in the contention that when a private right is conferred by a statute, the remedy for an infringement of that right has to be in terms of that statute and no other.
}

$I d$. The court further stated "[t]he expectation is that the patent holder will institute appropriate proceedings during the "monopoly" period to safeguard its rights in terms of Section 48 of the Patents Act. It does not require the DCGI's help in this." Id. para. 29.

175. Id. at para $22,25$.

176. Id. at para 28

177. Id. 
patent holder will institute appropriate infringement proceedings under patent law when it deems its rights to be infringed, and that patentees do not require the help of drug regulators to do so.178 For these reasons, pharmaceutical linkage was held to contravene the government's interest in public health by rendering patented drugs unaffordable and non-accessible. ${ }^{179}$ Bayer appealed to the Supreme Court of India, which dismissed Bayer's appeal based on its finding that the decision of the High Court of Delhi was well-reasoned and without error. 180

While one can look at India primarily as a jurisdiction with strong generic interests, the same cannot be said of the European Union, where many global pharmaceutical firms are based. In its 2009 Final Report of the Pharmaceutical Sector Inquiry, the E.C. stipulated that under E.U. law regulatory approval is not linked to patent status, nor can the same be used to "refuse, suspend or revoke marketing authorisation."181 Echoing the decision of the High Court of Delhi in Bayer, the Commission specified that

The task of marketing authorisation bodies is to verify whether a medicinal product is safe, effective and of good quality. Their main function is to ensure that the pharmaceutical products reaching the market are not harmful to public health. Other factors, such as the patent status of the product, should therefore not be taken into account when assessing the risk/benefit balance of a medicine. ${ }^{182}$

Of interest, while some jurisdictions have vetted the convergence of food and drug law and patent and industrial law

\footnotetext{
178. Id.

179. Id. para. 30 .

180. Bayer Corporation v. Union of India, SLP 6540/2010 (Ind.).

181. See Final Report, supra note 22, at 315 n.514:

Article 81 of Regulation (EC) 726/2004 and Article 126 of Directive (EC) $2001 / 83$ provide that an authorisation to market a medicinal product shall not be refused, suspended or revoked except on the grounds set out in the Regulation and the Directive. Considering that patent status is not included in the grounds set out in the Regulation and the Directive, it cannot be used as an argument to refuse, suspend or revoke a marketing authorisation. The Commission may launch infringement proceedings against any Member State which infringes the Directive.
}

Similarly, in South Korea, the drug approval authority does not take into account the patent status on the ground that the drug approval authority is not competent to do so. Pharmaceutical Affairs Law Enforcement Regulations, Health and Welfare Ordinace No. 32, art. 43(7) (Dec. 30, 2010) (S. Kor.). Only when a court confirms a patent infringement is the drug approval cancelled ex post. See id.

182. Preliminary Report, supra note 22, at 261. 
(United States, Canada, Mexico, and Australia) and others have rejected it (European Union, India), some jurisdictions seem to be trying to juggle both ends of the balance in order to gain a measure of linkage without explicit law. For example, as noted above pharmaceutical linkage is not the law of the European Union. However, in its report, the E.C. noted that several jurisdictions had nevertheless attempted to implement some form of linkage, including Hungary, Portugal, the Slovak Republic, and Italy. ${ }^{183}$

The Mexican Supreme Court recently held that the main function of pharmaceutical linkage is explicitly to provide the legal grounds for the regulatory authority to reject marketing authorizations that are deemed to violate patent rights. ${ }^{184}$ The court held that the purpose of listing patents on the patent register is to establish a link between the grant of marketing authorization by health the authorities and industrial property authorities that are in charge of granting and protecting patent rights for the exclusive use of inventions. ${ }^{185}$ The court went one step further, clarifying that under such linkage it is the proper job of the regulatory authority to reject marketing authorizations which violate the rights derived from relevant patents. 186 As such, the Mexican Supreme Court has clearly embraced the convergence of public health and industrialeconomic policy.

From the discussion thus far, it can be seen that different jurisdictions have grappled with the issue of the convergence and/or divergence of health policy and industrial and economic policy with significantly differentiated outcomes. More research is necessary to parse out in detail the differing policy grounds, public policy values, free trade agreement power imbalances, and legislative debates preceding linkage in these jurisdictions in order to arrive at whatever unified rules may be at play in these divergence outcomes, if any.

183. See Final Report, supra note 22, at 316 tbl. 24.

184. Mexican Supreme Court Decides on Broad Interpretation of Linkage Regulations, PATENT DOCS (Mar. 9, 2010, 11:43 PM), http://www.patentdocs.org/2010/03/mexican-supreme-court-decides-on-broadinterpretation-of-linkage-regulations.html.

185. See Alejandro Luna, Supreme Court upholds the worth of formulation patents, OLIVARES \& CIA, http://www.olivares.com.mx/Knowledge/Articles/IPLitigationArticles/Supreme Courtupholdstheworthofformulationpatents (last visited June 13, 2011).

186. Id. 


\section{Expansion of Linkage Beyond the Drug APPROval-Drug} PATENTING NEXUS

There is growing recognition that the system of pharmaceutical linkage regulation is aggressively expanding not only geographically, ${ }^{187}$ but also in scope. ${ }^{188}$ This expansion has the potential to significantly impact domestic systems of intellectual property, but may also strongly influence the movement of drugs intended for humanitarian purposes between nations. As such, it is possible that linkage between market authorization and drug patenting may be providing an important legal template for expansion of linkage into other realms involving pharmaceutical products.

The recent E.C. Report of the Pharmaceutical Sector Inquiry is a case in point. 189 The report represents the first clear articulation of policy reasons for opposition to linkage from a major economic region. ${ }^{190}$ It also clearly outlines an expansive legal concept of pharmaceutical linkage. The Preliminary Report, issued in November 2008, provided a list of existing and emerging patent linkages inherent to what the Sector Inquiry described as a "tool-box of instruments and measures for how to prepare for and react to generic entry."191

The tool-box described by the E.C. focuses on the concept of pharmaceutical linkage. The range of described linkage practices encompassed the linkage of patent status not only to market authorization, but also to: contracts, disputes, and litigations between originator and generic companies; opposition procedures and appeals before patent offices; patent settlements and other agreements between originator and generic companies; promotional activities, including an

187. See Correa, supra note 14, at 401 (explaining that U.S. Free Trade Agreements require a linkage between drug market authorization and patents).

188. See Final Report, supra note 22, at 131.

189. Id. at 480 ("The Commission will continue to strictly enforce the applicable Community law and, for instance, act against patent linkage, as according to Community legislation, marketing authorisation bodies cannot take the patent status of the originator medicine into account when deciding on marketing authorisations of generic medicines."). In the Preliminary Report, the E.C. stated more specifically that Patent-linkage is considered unlawful under Regulation (EC) No 726/2004 and Directive (EC) No 2001/83. Preliminary Report, supra note 22, at 15. For further elaboration, see discussion supra note 35.

190. See Final Report, supra note 22.

191. Preliminary Report, supra note 22, at 22. 
emphasis on follow-on and other second generation products; as well as a range of interventions by brand firms before national authorities pertaining to marketing authorization, drug pricing, and reimbursement. 192

An evolving landscape such as this raises the question of whether the pharmaceutical industry is using linkage as an expansive legal and public policy tool to reach across national borders. Further research is necessary to elucidate the grounds and potential impact of this claim, both nationally and globally.

\section{E. Rights Layering V. Single Point Mechanism For INCENTING INNOVATION}

Emerging empirical data on incremental innovation and linkage regulations, ${ }^{193}$ particularly when taken in combination with historical studies of patent protection for pharmaceuticals, ${ }^{194}$ have demonstrated a growing sophistication in the ability of pharmaceutical firms to layer patent and other intellectual property rights on pharmaceutical products at numerous stages of drug development. When combined with conventional patent law and the evidentiary requirements for new and follow-on drug approval, linkage regimes appear to provide a powerful tool for multinational pharmaceutical firms to efficiently and effectively identify attractive new and follow-on drug candidates for prolonged market exclusivity at various stages of the product lifecycle.

The linkage regime in particular has proven to be a valuable tool for firms to obtain enhanced legal protection on drugs at all stages of development, including drugs about to

192. See discussion supra note 36.

193. See Bengt DomeiJ, Pharmecutical Patents In Europe (2000) (noting the linkage between the pharmaceutical industry and patent legislation in Europe and how European patent law allows the exclusion of competition for products on a fixed time scale); Bengt Domeij, Initial and Follow-on Pharmaceutical Inventions in Europe, in ECONOMICS, LAW AND INTELLECTUAL PROPERTY 177-98 (Ove Granstrand, ed., 2003) (examining court decisions in Europe and identifying ways in which courts can create extra incentives for valuable follow-on inventions); Bouchard \& Sawicka, supra note 110, at 57-58; see generally Bouchard et al., Who's Leading Whom?, supra note 12, at 1509-21 (discussing the impact of linkage and other regulations on drug creation); Bouchard et al., Drug Approval-Drug Patenting, supra note 12, at 189-216; Hemphill \& Lemley, supra note 13; Hemphill \& Sampat, supra note 13.

194. See generally BESSEN \& MEURER, supra note 3; BOLDRIN \& LEVINE, INTELLECTUAL MONOPOLY, supra note 3. 
come off patent protection, drugs moving through the regulatory approval stage, and drugs that are currently in development.195 The number and array of patent types, the speed of patent listing, the automatic injunction, and the low relevance requirement for listing combined with low evidentiary requirements for new and follow-on drug approval enable pharmaceutical firms to rapidly identify attractive drug targets for legal protection both during and after regulatory approval. Added to patent linkage is the data exclusivity regime which, depending on the country being considered, now provides for up to 11.5 years of market exclusivity for products based on the confidentiality of regulatory submission data. ${ }^{196}$ When gauged against reports indicting declining levels of innovation in the pharmaceutical industry, ${ }^{197}$ be it from a loss of low hanging fruit, 198 increasing research and development costs, 199 or firms aiming ex ante at legal targets offering high reward for low risk drug development, 200 the question arises of whether numerous layers of intellectual property protection, and the corresponding extension of market exclusivity, are

195. Bouchard et al., Drug Approval-Drug Patenting, supra note 12 at 18182.

196. Alexander Stack, Canada: Trade-Driven Changes Coming to Canadian Patent and Data Protection Laws? Canada-European Union Trade Negotiations, MONDAQ (Jan. 11, 2011), http://www.mondaq.com/canada/article.asp?articleid=106048.

197. See, e.g., Brian Guthrie \& Trefor Munn-Venn, Conference BD. OF CANADA, SiX QUick Hits For CANADIAN COMMERCIALIZATION 1 (Apr. 2005), available

at, http://www.angelinvestor.ca/userfiles/file/IPTC/Supporting\%20Docs\%20for\%20 IPTC/IPTC\%20Conf\%20Brd\%206\%20Quick\%20Hits.pdf; Reinventing Innovation and Commercialization Policy in Ontario 44 (Inst. for Competitiveness \& Prosperity, Working Paper No. 6, 2004), available at http://www.competeprosper.ca/images/uploads/wp06.pdf.

For a discussion of the decline in innovation in the broader sciences, see generally EXPERT PANEL, supra note 58; COUNCIL ON COMPETITIVENESS, INNOVATE AMERICA 22-25 (2005), available at http://www.compete.org/images/uploads/File/PDF\%20Files/NII_Innovate_Ame rica.pdf; COUNCIL ON COMPETITIVENESS, FIVE FOR THE FUTURE 18 (2007), available http://www.compete.org/images/uploads/File/PDF\%20Files/Five_Final_8858C OC.pdf.

198. Fredric J. Cohen, Macro Trends in Pharmaceutical Innovation, 4 NATURE REVS. DRUG DISCOVERY 78, 82 (2005), available at http://www.nature.com/nrd/journal/v4/n1/pdf/nrd1610.pdf.

199. Joseph A. DiMasi et al., The Price of Innovation: New Estimates of Drug Development Costs, 22 J. HEALTH ECON. 151, 158 (2003).

200. See Bouchard et al., Who's Leading Whom?, supra note 12, at 1509-13. 
encouraging or stifling innovation in the pharmaceutical sector. ${ }^{201}$

It may be that one, not both, mechanisms for protecting innovative drugs will prevail in the long run. For example, in its review of patent term extension under Hatch-Waxman, the U.S. Congressional Budget Office noted that shortening of drug review times may be a more effective means of stimulating innovative research rather than further lengthening patent protection since millions of dollars in sales are lost for each extra day a drug stays in the approval process. ${ }^{202}$

Given that regulatory review times have declined substantially over the last two decades globally in the context of user fees, ${ }^{203}$ one could ask what is the public interest in expanding patent terms via the linkage regime either alone or concomitant with data exclusivity and patent term restoration? Is it in the public interest to continue to link drug approval with patent protection to produce multiple layers of exclusivity protection? Does the convergence mechanism hold up if the economic goals of linkage are not being met?

These questions are vital from a public health perspective, as the growing data exclusivity regime is a nearly perfect substitute for patent linkage. How a given nation addresses each will impact generic entry and thus cost savings and access to essential medications.

\section{F. Role of Empirical Studies for Public Health Systems}

Finally, there is the thorny issue of the relevance of empirical research on pharmaceutical patents for the making of law and policy ex ante as well as its ex post review. At this point in time, we are witnessing an influx of highly qualified personnel into the field of law with previous experience in the hard empirical sciences, particularly the medical sciences. Unlike schools of medicine, management, and business at the

201. See generally Bouchard et al., Drug Approval-Drug Patenting, supra note 12 , at 181-82 (discussing the impact patents and linkage regulations have on the activities of pharmaceutical companies in terms of their tendency to produce new versus follow-on drugs).

202. Glasgow, supra note 25, at 256-57.

203. For relevant information regarding review times, see generally Joel Lexchin, Commentary, Drug Withdrawals from the Canadian Market for Safety Reasons, 1963-2004, 172 CAN. MED. Ass'N J. 765, 772 (2005), available at http://www.cmaj.ca/cgi/reprint/172/6/765. 
end of the first decade of the twenty-second century, schools of law, legal systems, and the judiciary are just beginning to realize the full potential of empirical legal research to contribute to law-making and law reform in areas of law that are heavily contingent on science.

Indeed, there is a growing discordance between the policy grounds underpinning the pharmaceutical linkage and the results of empirical studies intended to assess their effectiveness, as well as that of the patent system more generally in providing incentives for innovation. As noted above, the goal of the linkage regime is often cited as balancing the conflicting policy goals of facilitating the development of new and innovative drugs and timely generic entry. Yet a number of studies have been published recently that report largely negative results on the impact of linkage regulations on the approval of new drugs, the timeliness of generic entry, and the extension of market exclusivity on blockbuster products coming off patent due solely to linkage. ${ }^{204}$

The results of empirical studies such as these have profound ramifications for assessing how well the linkage regime works as currently constituted and thus enables conclusions as to the vires of legislation when gauged against its original policy goals. It has been demonstrated, for example, that loopholes in linkage laws, as they operate in tandem with low evidentiary requirements for drug approval, can provide for clustering of follow-on drugs and related patents, and that these clusters of drugs and patents can substantially extend the cumulative patent life of older blockbuster drugs by as much as a factor of two. ${ }^{205}$

Even when considering only the extension of market exclusivity-when all relevant patents listed on the patent register have been litigated and found to be invalid or not infringed-linkage still delays generic entry by three to five years. ${ }^{206}$ This can be compared to the seven month (weighted average) delay for generic entry following the loss of patent protection in the European Union in the absence of linkage. 207 The E.C. Pharmaceutical Sector Inquiry recently found that

204. For a review of these studies, see Bouchard, I'm Still Your Baby, supra note 5, at 77-94.

205. Bouchard et al., Who's Leading Whom?, supra note 12, at 1497-94.

206. See id. at 1505-06

207. Final Report, supra note 22, at 8. 
over the period studied, savings from generic entry of medications would have been twenty percent greater if entry had taken place immediately following the loss of brand exclusivity. 208 Thus, the lag between the loss of brand exclusivity and generic entry, and the contribution thereto by linkage laws, is critical for public health savings from a qualitative as well as quantitative perspective.

In addition to obtaining data pertaining to drug approval, litigation and innovation, it is necessary to investigate the relationship of this data to those for sales and profit data before and after linkage regulations came into force, the fractional cost of generics at different points in the product lifecycle compared to brand products across jurisdictions, as well as how linkage regulations in different jurisdictions determine the duration of market exclusivities and their impact on the price of brand and generic drugs, particularly before and after litigation under various linkage provisions has terminated. The growing cache of empirical data on pharmaceutical linkage may be of increasing importance as numerous jurisdictions worldwide are in the process of revising, rejecting or enacting pharmaceutical linkage regulations. Empirical evidence as to the successes and failures of different forms of linkage would therefore be valuable, both domestically and globally.

Discordance between claims for pharmaceutical linkage and the so-called "real world" effects of linkage on drug development are not new. For example, in the political debate leading up to repeal of compulsory licensing and the coming into force of the Canadian regulations, an evidence-based approach to drug patenting and pharmaceutical linkage was explicitly rejected by Parliament. ${ }^{209}$ During the hearings, a U.S.-based economist specializing in drug development gave evidence as to the importance of empirical studies when assessing linkage regulations, suggesting that a HatchWaxman-like linkage regime would enhance market exclusivity for blockbuster drugs several-fold more than anticipated to the detriment of payers in the absence of demonstrable increases in national research and development capacity. ${ }^{210}$ The evidence demonstrated that multiple patents per drug would be affected

208. Id. at 9 .

209. See Bouchard, I'm Still Your Baby, supra note 5, at 102 n.53.

210. Id. at 104-05. 
and that the average delay for generic entry would be on the order of ten to fifteen years. ${ }^{211}$ The data were discounted in favor of the unsupported claim that only one patent per drug would be affected, the average delay in generic entry would be minimal, and the tacit assumption that increased patent protection would yield both increased innovation and public welfare. ${ }^{212}$ There appeared to be no middle ground during the negotiations or a reasonable appreciation for the value of empirical data to the debate. ${ }^{213}$ A similar situation evolved in the United States following the enactment of Hatch-Waxman, which was addressed in subsequent amendments to the legislation. ${ }^{214}$

Data from our early work on global pharmaceutical linkage indicate that the debate over the value of empirical data for law-making relative to linkage regulations is far from over and indeed may be taking on new relevance. Jurisdictions that were not ready to address what may have been seen as an isolated study during the original debates over linkage 215 are now faced with mounting empirical work on pharmaceuticals and

211. Id. at 105; Tancer, supra note 9, at 294 .

212. Bouchard, I'm Still Your Baby, supra note 5, at 104.

213. See id. at 102 n.53.

214. Epstein \& Kuhlik, supra note 8, at 14 n.29; Avery, supra note 8, at 184-87. It was recognized as early as 2001 that pharmaceutical patent reforms such as linkage regulations could extend the average patent life of pharmaceuticals by at least fifty percent. Glasgow, supra note 25, at 233. In its 2002 report, the FTC reported that approximately twenty-eight percent and thirty-five percent of patents were either invalid or uninfringed, respectively, suggesting that undue prolongation of patent monopolies under Hatch-Waxman Act constituted abuses of linkage law. See FED. TRADE ComM'N, supra note 11, at 20. Four years later, the U.S. Congressional Budget Office noted that the number of new pharmaceutical products was declining. CONG. BUDGET OFFICE, RESEARCH AND DEVELOPMENT IN THE PHARMACEUTICAL INDUSTRY (2006), available at http://www.cbo.gov/ftpdocs/76xx/doc7615/10-02-DrugR-D.pdf. This decrease came even as patent protection for pharmaceuticals had escalated. Jaffe, supra note 3, at 531. Results such as these prompted Kesselheim \& Avorn to note in 2006 that legal exclusivity periods in the pharmaceutical sector had already produced a wide range of negative effects on public health, including making essential medications unaffordable to developing nations, preventing dissemination of patented processes for vitamin fortification to underserved populations, limiting the ability of nations to manage epidemics, releasing new drugs only as combination therapies to avoid generic entry, and the inflation of drug prices. See Aaron S. Kesselheim \& Jerry Avorn, Biomedical Patents and the Public's Health: Is There a Role for Eminent Domain?, 295 JAMA 434, 434 (2006).

215. For a review of interpretation of Dr. Schondenmeyer's data in the Canadian context, see Bouchard, I'm Still Your Baby, supra note 5, at 104-05. 
patents, ${ }^{216}$ including linkage. ${ }^{217} \mathrm{~A}$ second conclusion is that jurisdictions outside North America appear to have taken lessons from those with previous experience more seriously in bringing in or rejecting domestic versions of linkage. An important issue to explore in future research on topic is what factors were seen by various jurisdictions as more or less important in their policy deliberations and what the likely reasons were for others to ignore these lessons. Moreover, learning what lessons were drawn from studies of the outputs from different systems of checks and balances in various jurisdictions, and how did these lessons inform the customization of pharmaceutical linkage in various jurisdictions will be important to understand.

Consider, for example, the comparative linkage experience in the European Union, Australia and South Korea. Studies conducted by Australian and European Union governments, demonstrated significant learning from experience and strong adaptation. Data obtained by the European Union was broad in scope, depth, and balance of analysis, and thus well informed linkage policy and law. ${ }^{218}$ Similarly, after intense deliberation and public debate, ${ }^{219}$ Australia introduced both express antievergreening provisions (involving damages and penalties) as well as a provision for pharmaceutical innovation to be defined based on considerations of "objectively demonstrated therapeutic significance" in its linkage regime, notwithstanding significant resistance from U.S. trade negotiators. 220 It remains to be seen whether this customized system of checks and balances will yield an empirically observable balance between the production of new and innovative drugs and timely generic entry.

216. E.g., BESSEN \& MEURER, supra note 3, at 88-91; BOLDRIN \& LEVINE, INTELLECTUAL MONOPOLY, supra note 3, at 212-38; see also ADAM B. JAFFE \& JOSH LERNER, INNOVATION AND ITS DISCONTENTS: HOW OUR BROKEN PATENT SYSTEM IS ENDANGERING INNOVATION AND PROGRESS, AND WHAT TO DO AвOUT IT 11-12 (2004).

217. A number of papers are dedicated to reviewing the various studies on linkage. See generally Bouchard et al., Who's Leading Whom?, supra note 12; Bouchard et al., Drug Approval-Drug Patenting, supra note 12; Sawicka \& Bouchard, supra note 12; Hemphill \& Sampat, supra note 13.

218. See generally Final Report, supra note 22; Preliminary Report, supra note 22 .

219. See generally Faunce et al., supra note 165.

220. Id. at 2; Faunce \& Lexchin, supra note 4 , at 5 . 
A similar comparison can be drawn from the differing experiences of the United States, India, Australia, South Korea, and Canada concerning allegations of evergreening abuses. Compared to its American counterpart, the government of Canada has been slow to respond to evergreening allegations and has minimized the negative effects of linkage on patent protection for blockbuster drugs in numerous internal studies released between 2004 and 2010.221 By comparison, the Supreme Court of India recently upheld the High Court of Delhi's rejection of pharmaceutical linkage, and the nation clearly sees itself as a leader on the issues of global pharmaceutical law and access to essential medication. ${ }^{222}$ Evergreening abuses have been addressed in a unique way in this nation using traditional patent law: India's 'patent law allows for filing of oppositions before the grant of a patent (pregrant opposition) which allows competitors (mostly generics) to challenge the validity of a patent application before its grant. 223 Indian companies have used pre-grant opposition to effectively challenge some of the most profitable drugs, including Glivec, Iressa, Tamiflu, and others. ${ }^{224}$

Why is Canada lagging behind the United States in its law reform efforts? Why is South Korea going forward even though its own data are projecting negative domestic impacts? Why have some jurisdictions such as Australia and India responded quickly and effectively to public interest concerns in bringing in, amending, and/or rejecting their domestic linkage regimes and what lessons are there for other jurisdictions?

One possible obstacle to effective policy-making and/or law

221. See supra note 52 and accompanying text.

222. See Delhi High Court Rejects Bayer's Appeal for Patent Linkage, EuR. AIDS TREATMENT GROUP (Oct. 2, 2010), http://www.eatg.org/eatg/Global-HIVNews/Access-to-treatment/Delhi-High-Court-rejects-Bayer-s-appeal-forpatent-linkage.

223. Feroz Ali Khader, The Touchstone Effect: The Impact of PreGRANT OPPOSITION ON PATENTS 39-40 (2008).

224. AstraZeneca's Iressa Patent Application Rejected in India, INDIAN PATENT OPPOSITIONS (Nov. 20, 2007, 11:05 PM), http://indianpatentoppositions.blogspot.com/2007/11/astrazenecas-iressapatent-application.html; Varun R. Chhonkar, Indian Patent Office Rule Against Gilead in Tamiflu PreGrant Opposition, PATENTCIRCLE (April 15, 2009), http://patentcircle.blogspot.com/2009/04/indian-patent-office-ruledagainst.html; Joe C. Matthew, India Rejects Patent to Glivec's Second Variant, REDIFF INDIA ABROAD (April 15, 2009), http://www.rediff.com/money/2009/apr/15india-rejects-patent-to-glivecvariant.htm. 
reform is that linkage regulations are complex and not widely understood. This is consistent with the observation in Bayer $v$. India to the effect that there is no uniformity in the linkage policy of different countries. ${ }^{225}$ Hence, there is great value in comparative legal analysis of different linkage systems worldwide.

A related and important issue is the manner in which courts in different jurisdictions view the role of empirical data in the context of an evolving legal landscape, particularly with respect to technology-heavy areas of the law such as intellectual property. ${ }^{226} \mathrm{~A}$ pertinent question that arises is how should courts and law-makers react when empirical evidence demonstrates that a particular piece of legislation is not achieving its stated goals? Can such data support the conclusion that the legislation is invalid or in need of substantial amendment in order for it to remain intra vires? Are there aspects of statutory interpretation in various jurisdictions that illuminate an investigation into whether the local linkage laws are meeting the stated goals of stimulating the development of new and innovative drugs and facilitating timely entry of generic drugs and if not what should be done about it? An ancillary question is whether appellate courts in different jurisdictions view law as "live" or "fixed"-and thus more or less amenable to ex post empirical analysis.

There is some work to suggest that it may be useful to investigate the vires of pharmaceutical linkage from a purposive perspective, using ordinary language of linkage statutes informed contextually by the scheme, purpose and evidence of statutory intent.227 This approach supports an important role for external context, referring to the interface between original policy intent and the consequences of how legislation works operationally in the real world.228 Taking an

225. Bayer Corp. v. Union of India, LPA 443/2009, para. 32 (Delhi H.C.) (India).

226. Burk \& Lemley, supra note 2, at 1579.

227. Purposive analysis of statutory text looks to the "material goals the legislature hoped to achieve [and] the reasons underlying each feature of the implementing scheme." RUTH SULLIVAN, SULlivaN AND DRIEDGER ON THE CONSTRUCTION OF STATUTES 204 (4th ed. 2004). Using evidence in interpretation "can be helpful in understanding the meaning of legislative language ... [and] expos[ing] and dispel[ling] misconceptions that distort interpretation." Id. at 469.

228. See Hutchinson, supra note 46 , at 33. 
"evidence-based" approach to the assessment of vires in a technology-intensive sector such as pharmaceuticals resonates particularly well with the state of global drug regulation, which has clearly and strongly evolved toward "real world" or evidence-based lifecycle models of drug approval for the last two decades. 229

If drug approval and drug patenting are becoming increasingly evidence-based, there is no reason why the legal linkage between the two should not do so as well. An evidencebased approach to vires is supported by the objective of identifying the mischief a given piece of legislation was intended to remedy at the time it was enacted. ${ }^{230}$ In the case of linkage statutes or regulations, this exercise would likely be contingent both on an understanding of the original policy intent underpinning local linkage regimes as well as their enabling statutes, typically patent legislation. ${ }^{231}$ When courts are presented with competing interpretations of law (e.g., public health or economic; patent law or food and drug law), is the clear choice one that accords substantively with a legislative purpose that is consistent with an interpretation of the statute as a workable whole?232 As noted by Fuller:

The troublesome cases are in reality resolved not in advance by the legislator, but at the point of application . . . . All this adds up to the conclusion that an important part of the statute in question is not made by the legislator, but grows and develops as an implication of complex practices and attitudes which may themselves be in a state of development or change. ${ }^{233}$

In this view, the purpose of law is not static but rather a

229. Hans-Georg Eichler et al., Balancing Early Market Access to New Drugs with the Need for Benefit/Risk Data: A Mounting Dilemma, 7 NATURE REVS. DRUG DISCOVERY 818, 823-24 (2008). For a discussion of the relevance of lifecycle models to pharmaceutical linkage, see generally Sawicka \& Bouchard, supra note 12, at 109-15.

230. Hutchinson, supra note46, at 7 (citing WILLIAM N. ESKRIDGE Jr. ET AL., LEGISLATION AND STATUTORY INTERPRETATION 226-27 (2nd ed. 2006)).

231. Bouchard, I'm Still Your Baby, supra note 5, at 107-09.

232. LON L. FULLER, ANATOMY OF THE LAW (1968) [hereinafter Fuller 1968]; Lon L. Fuller, Positivism and Fidelity to Law - A Reply to Professor Hart, 71 HARV. L. REV. 630, 667 (1957) [hereinafter Fuller 1957].

233. Fuller 1968, supra note 232, at 59. As noted by Hutchinson:

The process of interpreting statute is not just drawing out what legislators put into it, but adjusting the statute to the implicit demands and values of the society to which it is to be applied. In this sense it may be said that no enacted law ever comes from its legislator wholly and fully made.

Hutchinson, supra note 46, at 24 n.129 (internal quotation marks omitted). 
dynamic process of refining and clarifying means and ends through a system of positive and negative feedback loops. ${ }^{234}$ The purposive analysis thus privileges evidence of how a law operates in the lives of people affected by it, not theoretically or hypothetically as an isolated idea or goal. In an analytical framework of this nature, objective evidence of the operation of statutes and regulations such as empirical evidence of contextual operational efficiency is paramount. ${ }^{235}$

The notion that law is "alive" rather than stagnant draws strong parallels to legal scholarship demonstrating law to be a dynamic complex adaptive system. ${ }^{236}$ In such systems, law-inoperation is strongly contingent on evidence relating to positive and negative feedback loops that impact on system performance, including empirical data relating to systems of intellectual property law and biomedical innovation.

\section{SUMMARY \& CONCLUSIONS}

Compared to the traditional patent system, pharmaceutical linkage regulations represent a novel and evolving intellectual property paradigm for pharmaceutical products. Even so, this regime is rapidly evolving in a global context, and is poised to become an important determinant of the availability and cost of essential medications worldwide. In this Article, the authors, representing a global network of scholars and practicing lawyers, lay out a novel framework for a comparative legal analysis of global pharmaceutical regulations.

A major goal we have identified is to investigate the structural and functional aspects of global linkage regulations as they relate to drug availability, costs, and expenditures on the one hand and incentives for innovation and protection of rights on the other. Structure-function analyses in the life sciences have lead to numerous key insights into molecular, cellular, tissue, organ, and whole body functioning over the last half-century. In all of these areas of study, a key observation has been that structure not only influences function, but function also influences structure through an array of positive

234. See Hutchinson, supra note 46 , at 24 .

235. Id.

236. See, e.g., J. B. Ruhl, Thinking of Environmental Law as a Complex Adaptive System: How to Clean Up the Environment by Making a Mess of Environmental Law, 34 Hous. L. REV. 101, 109-29 (1997). 
and negative feedback loops.

This body of work in the medical sciences applies fundamentally to law in two ways. First, because governments have specific legal and policy goals in mind when drafting law and regulations, and these goals are expressed in the form of discrete legal and regulatory language. And second, because the policy goals and statutory language referred to above are reviewable by courts in judicial review and other proceedings. In addition these goals and statutes may, and often are, revisited by governments in the context of their law reform efforts.

Here, we show that the structure-function paradigm can also be a valuable tool for the study of law, particularly the comparative analysis of the effects of different legislative and regulatory tools on the pharmaceutical innovation ecology. In particular, we demonstrate that differences in the discrete statutory mechanisms underpinning pharmaceutical linkage in different jurisdictions, and the way these mechanisms interact with relevant provisions of patent and food and drug law, have the potential to substantially alter outcomes and outputs in relation to the balance of encouraging the development of new and innovative drugs and facilitating timely generic entry.

A unique advantage of the structure-function methodology proposed in this Article is that studying linkage in different jurisdictions in this manner allows for both an investigation of the structural and functional characteristics of local linkage regimes with different initial starting conditions and different legal mechanisms of operation and the identification of general rules of linkage as the different national forms of linkage interact and influence global pharmaceutical regulation. The former provides a descriptive mechanism for assessing the successes and failures of different regimes while the latter provides a prescriptive approach for key decision makers to revise, institute or abolish linkage regulations according to the goals and objectives of differing nations.

The specific structural and functional aspects we discuss here include, inter alia: assessment in each jurisdiction of the original policy intent underpinning linkage; the specific legal grounds underpinning linkage in various jurisdictions, in particular the Bolar provision and how this provision interacts with other policy levers intended to stimulate innovation while also making generic drugs available faster; the manner in which public health policy and economic policy is perceived by 
[Vol. 12:2

governments and the courts to converge or diverge through linkage; the specific legal checks and balances designed specifically to maintain balance between the interests of brand and generic firms; the growing expansion of linkage beyond the drug approval-drug patenting nexus to encompass drug pricing and reimbursement; and the role of empirical studies to establish the legal legitimacy of linkage regulations.

The goal of the work outlined here is to explicate the different outputs and outcomes of pharmaceutical linkage in different jurisdictions, and relate this understanding to among other things fundamental differences in statutory language and original policy intent in different jurisdictions. A further goal is to assist key decision-makers in domestic and global governments and legal systems working with linkage regimes in their efforts to stimulate the production of new and innovative drugs while at the same time facilitating timely generic entry, lowering public health costs, and increasing access to essential medicines. 